\title{
Fine-scale spatial and temporal genetic structure of Atlantic cod off the Atlantic coast of the USA
}

\author{
Adrienne I. Kovach ${ }^{1, *}$, Timothy S. Breton ${ }^{2}$, David L. Berlinsky ${ }^{2}$, Lorraine Maceda ${ }^{3}$, \\ Isaac Wirgin ${ }^{3}$
}

\author{
${ }^{1}$ Department of Natural Resources and the Environment, and ${ }^{2}$ Department of Biological Sciences, University of \\ New Hampshire, 46 College Road, Durham, New Hampshire 03824, USA \\ ${ }^{3}$ Department of Environmental Medicine, New York University School of Medicine, 57 Old Forge Road, Tuxedo, \\ New York 10987, USA
}

\begin{abstract}
Atlantic cod Gadus morhua in US waters are currently managed as 2 stocks: (1) a Gulf of Maine stock and (2) a Georges Bank and south stock. This designation is decades old and warrants re-evaluation in light of concerns that fisheries management units may not reflect biologically meaningful population units. In this study, we used 10 microsatellite loci, the PanI locus, and 5 single nucleotide polymorphism markers to characterize the population genetic structure of cod in US waters. We found significant differentiation among temporally and spatially divergent populations of cod (global $F_{\mathrm{ST}}=0.0044$ ), primarily stemming from 2 potentially non-neutral loci, and evidence for a population structure that strongly contradicts the current 2-stock management model. This genetic structure was stable over a 5 yr period. Our results indicate that cod in US waters are broadly structured into 3 groups: (1) a northern spring-spawning coastal complex in the Gulf of Maine (GOM), (2) a southern complex consisting of winter-spawning inshore GOM, offshore GOM and sites south of Cape Cod, Massachusetts, and (3) a Georges Bank population. The strongest differentiation occurs between populations in the northern and southern complex (mean $F_{\mathrm{ST}}=0.0085$ ), some of which spawn in the same bays in different seasons. By means of mixture analysis, young-of-the-year fish sampled on juvenile nurseries were assigned to the spawning complex of their origin. Our findings contribute to a growing body of knowledge that Atlantic cod and other marine fish populations are structured on a finer scale than previously thought and that this structure supports biocomplexity and locally adapted populations. As such, it may be warranted to re-evaluate current management units and tailor management plans toward this finer scale.
\end{abstract}

KEY WORDS: Atlantic cod · Microsatellite DNA · Single nucleotide polymorphism · Population genetic structure $\cdot$ Stock identification · Gadus morhua

Resale or republication not permitted without written consent of the publisher

\section{INTRODUCTION}

Marine fish populations have long been viewed as demographically open with high connectivity, owing to vagile, pelagic larval stages and high adult migratory potential. This classical view of marine fish species (Hauser \& Carvalho 2008) was supported by tagging studies that demonstrated long distance migrations (Templeman 1974) and by early genetic studies that revealed high levels of gene flow (Ward et al. 1994). This perspective influenced management regimes, such that many marine fisheries are managed as broadly distributed, panmictic populations (Pampoulie et al. 2006). Overwhelming evidence now suggests that, rather than being demographically open, many marine species exhibit population subdivision on fine geographic and temporal scales (reviewed in Hauser \& Carvalho 2008). A growing body of literature points to 
the importance of processes that limit dispersal and promote self-replenishment of local populations, such as sedentary adult life history strategies (Robichaud \& Rose 2004, Howell et al. 2008), spawning site fidelity (Taggart 1997), natal homing (Thorrold et al. 2001, Svedäng et al. 2007), egg and larval retention (Jones et al. 1999, 2005, Knutsen et al. 2007, Bradbury et al. 2008) and local adaptation (McIntyre \& Hutchings 2003, Conover et al. 2006, Hutchings et al. 2007). The implications of such fine-scale population structure are important for effective management (Palumbi 2003, Bradbury et al. 2008, Reiss et al. 2009).

One marine fish species known to exhibit fine-scale population structure in parts of its distribution is Atlantic cod Gadus morhua L. (see reviews in Wirgin \& Waldman 2005 and Hauser \& Carvalho 2008). Atlantic cod is one of the most commercially important marine fishes in the world and comprises a principal component of the northeastern US groundfish assemblage. Cod are distributed throughout the temperate continental shelf waters of both the northwest and northeast Atlantic Ocean (Collette \& Klein-MacPhee 2002). This species was once one of the most plentiful food fishes in the Gulf of Maine and has been a mainstay of fisheries since the 17th century (Mayo \& Col 2006). The high desirability of cod led to dramatic overharvesting and significant decline of most stocks across its range (Collette \& Klein-MacPhee 2002). There is growing concern that lack of recovery of cod stocks may be hampered by flawed management regimes that fail to recognize biologically meaningful population units (Smedbol \& Stephenson 2001, Pampoulie et al. 2006). While cod population structure has been the subject of extensive study in the northeast Atlantic (e.g. Hutchinson et al. 2001, Knutsen et al. 2003, 2007, Nielsen et al. 2003, Jorde et al. 2007) and in Canadian waters (Ruzzante et al. 1996b, 1998, 2000, Beacham et al. 2002), it has received much less attention in US waters (Lage et al. 2004, Wirgin et al. 2007). Much of the genetic diversity in this species may reside in smaller sedentary populations that may be particularly vulnerable to overharvest (Robichaud \& Rose 2004).

Atlantic cod in US waters are currently managed by a 2-stock model consisting of (1) a Gulf of Maine (GOM) stock and (2) a stock encompassing Georges Bank and areas southward, from southern New England to the mid-Atlantic coast. Recent evidence, including the results of tagging studies, suggests that cod movements do not conform to the 2-stock model (Tallack 2009). This is also supported by genetic data that suggest restricted gene flow among the Georges Bank and more southern populations as well as heterogeneity within the GOM (Lage et al. 2004, Wirgin et al. 2007). By tailoring fisheries guidelines to a flawed 2-stock model, management practices may negatively affect the smaller and more vulnerable populations (Larkin 1977, Iles \& Sinclair 1982, Ruzzante et al. 1999, Pampoulie et al. 2006, Bradbury et al. 2008).

In this study, we provided the most comprehensive analysis of Atlantic cod population structure in US waters to date. By means of microsatellite and single nucleotide polymorphism (SNP) markers and the PanI locus, we expanded on our previous research (Wirgin et al. 2007) in which we found evidence for an alternate interpretation of management units. Previously, we found genetic differences on a temporal scale, such that a spring-spawning population of cod in Ipswich Bay, New Hampshire-Massachusetts, was differentiated from winter-spawning cod from all other sites within the GOM (including the same bay), Georges Bank and sites south of Cape Cod, Massachusetts. We also found evidence that cod spawning on the northeast peak of Georges Bank may be differentiated from populations south of Cape Cod. In the present study, we aimed to develop a more detailed model of stock structure of cod in US waters, by evaluating the genetic structure of all major identifiable spawning aggregations over a 2 yr period. Our objectives were to (1) characterize the fine-scale population structure of spatially and temporally separated spawning aggregates of Atlantic cod, (2) investigate the temporal stability of the genetic structure using replicate samples collected over a 2 to 5 yr period, and (3) determine whether young-of-the-year cod sampled at juvenile nurseries could be assigned effectively to their population of origin.

\section{MATERIALS AND METHODS}

Sample collection. Atlantic cod were sampled from known spawning locations from inshore and offshore GOM, Georges Bank and south of Cape Cod from December 2005 to July 2008. Adult $\operatorname{cod}(\mathrm{n}=1581$; length, 54 to $127 \mathrm{~cm}$ ) were captured with otter trawls, gill nets and hook and line, in collaboration with commercial and recreational fishers and fishery biologists. Spawning condition was assessed by visual inspection of the gonads or observations of 'running' milt or eggs by using the US National Marine Fisheries Service ovarian staging criteria (O'Brien et al. 1993). Caudal fin clip samples $\left(1 \mathrm{~cm}^{2}\right)$ were taken from each fish and preserved in 95 to $100 \%$ ethanol.

Adult cod in spawning condition were sampled from spawning grounds at the northeast peak of Georges Bank, inshore GOM (in Bigelow Bight off the southern coast of Maine, Ipswich Bay and Massachusetts Bay), offshore GOM (on Jeffrey's Ledge and Stellwagen Bank) and south of Cape Cod (from the Nantucket Shoals and Cox Ledge) (Table 1, Fig. 1). 
Table 1. Gadus morhua. Abbreviated sample names, locations, dates collected, sample sizes (n), fishing gear used in sample collection and sexes (for adults) or length ranges (for juveniles only) of Atlantic cod sampled in this study. Reproductive conditions of adults are mean (range, single value means all sampled fish were in the indicated reproductive condition) and refer to National Marine Fisheries Service (NMFS) ovarian staging criteria as follows: 1: immature; 2: resting; 3: developing; 4: ripe; 5: ripe and running; 6: spent. Sample name codes are as follows: BBS: Bigelow Bight spring; IPS: Ipswich Bay spring; IPW: Ipswich Bay winter; MBW: Massachusetts Bay winter; MBS: Massachusetts Bay spring; PBS: Platts Bank spring; JLW: Jeffrey's Ledge winter; SWS: Stellwagen Bank spring; GBW: Georges Bank winter; NTW: Nantucket Shoals winter; CLW: Cox Ledge winter; CLS: Cox Ledge spring; NYS: New York Bight spring; NYW: New York Bight winter; CBSJ: Casco Bay spring juveniles; MBWJ: Massachusetts Bay winter juveniles; MBSJ: Massachusetts Bay spring juveniles; CCWJ: Cape Cod winter juveniles

\begin{tabular}{|c|c|c|c|c|c|c|}
\hline Sample name & Collection site & Date & $\mathrm{n}$ & Gear used & Sex & Reproductive condition \\
\hline \multicolumn{7}{|c|}{ Gulf of Maine inshore } \\
\hline \multirow[t]{2}{*}{ BBS } & Bigelow Bight & Jul 2007 & 70 & Trawl & Females & $6(6)$ \\
\hline & Bigelow Bight & Jul 2008 & 47 & Gill net & Mixed & $5(5)$ \\
\hline \multirow[t]{2}{*}{ IPS } & Ipswich Bay & Apr-May 2006 & 122 & Trawl & Mixed & $5(3-5)$ \\
\hline & Ipswich Bay & Jun 2007 & 78 & Trawl & Females & $6(6)$ \\
\hline IPW & Ipswich Bay & Dec 2006 & 31 & Trawl & Mixed & $2(2-5)$ \\
\hline \multirow[t]{2}{*}{ MBW } & Massachusetts Bay & Dec 2005-Jan 2006 & 140 & Gill net & Females & $4(3-6)$ \\
\hline & Massachusetts Bay & Jan 2007 & 77 & Trawl & Mixed & $5(3-5)$ \\
\hline \multirow[t]{2}{*}{ MBS } & Massachusetts Bay & Apr 2006 & 36 & Trawl & Females & $4(4-5)$ \\
\hline & Massachusetts Bay & Jun 2008 & 49 & Gill net & Females & $5(5)$ \\
\hline \multicolumn{7}{|c|}{ Gulf of Maine offshore } \\
\hline PBS & Platts Bank & Aug 2006 & 70 & Gill net & Mixed & $2(2,6)$ \\
\hline JLW & Jeffrey's Ledge & Dec 2007 & 73 & Trawl & Mixed & $5(3-5)$ \\
\hline \multirow[t]{2}{*}{ SWS } & Stellwagen Bank & May 2006 & 41 & Trawl, gill net & Mixed & $4(3-6)$ \\
\hline & Stellwagen Bank & Apr 2007 & 74 & Trawl & Mixed & $5(3-6)$ \\
\hline \multicolumn{7}{|l|}{ Georges Bank } \\
\hline \multirow[t]{2}{*}{ GBW } & NE Georges Bank & Feb 2006 & 152 & Trawl & Mixed & $5(3-6)$ \\
\hline & NE Georges Bank & Feb-Mar 2007 & 45 & Trawl & Mixed & $5(3-6)$ \\
\hline \multicolumn{7}{|c|}{ Southern New England } \\
\hline NTW & Nantucket Shoals & Nov 2006 & 109 & Trawl & Mixed & $4(3-6)$ \\
\hline CLW & Cox Ledge & Jan 2007 & 158 & Trawl & Mixed & $4(3-6)$ \\
\hline CLS & Cox Ledge & Apr 2007 & 118 & Trawl & Mixed & $4(3-6)$ \\
\hline NYS & New York Bight & Mar-Apr 2007 & 47 & Hook and line & Mixed & $2(2)$ \\
\hline NYW & New York Bight & Nov 2007-Jan 2008 & 44 & Hook and line & Mixed & $2(2)$ \\
\hline \multicolumn{4}{|c|}{ Gulf of Maine inshore juveniles } & \multicolumn{3}{|c|}{ Length range $(\mathrm{cm})$} \\
\hline CBSJ & Casco Bay & Apr 2007 & 45 & Trawl & $36-47$ & 1 \\
\hline MBWJ1 & Massachusetts Bay & Oct 2006 & 34 & Trawl & $3-15$ & 1 \\
\hline MBWJ2 & Massachusetts Bay & Oct 2007 & 48 & Trawl & $3-5$ & 1 \\
\hline MBSJ & Massachusetts Bay & Apr 2007 & 46 & Trawl & $3-5$ & 1 \\
\hline CCWJ & Cape Cod & Oct 2006 & 69 & Trawl & $3-15$ & 1 \\
\hline
\end{tabular}

Cod were not sampled north of Bigelow Bight due to a lack of fishing effort on the depleted populations of mid-coast and southeast Maine. When spawning cod could not be located at a presumed spawning site, adult cod not in spawning condition (identified as resting individuals) were sampled from aggregations in Ipswich Bay and Platts Bank, offshore coastal Maine and 48 to $113 \mathrm{~km}$ (30 to 70 miles) offshore from coastal New Jersey in the New York Bight. At Ipswich Bay, Massachusetts Bay and Cox Ledge, spawning cod were sampled in both the spring and winter; these seasonal collections were separated for analysis. To facilitate testing for annual fluctuations in genetic variation, 6 of the 10 spawning sites were sampled in 2 subsequent years (Bigelow Bight, Ipswich Bay, Massachusetts Bay winter and spring samples, Stellwagen Bank and Georges Bank).
Juvenile cod ( 3 to $15 \mathrm{~cm}$, age 0 to 1 based on age-atlength key of Kerr et al. 2009a) were sampled by bottom trawl from Massachusetts Bay in October 2006 and 2007 and April 2007, and off the coast of Provincetown, northeastern Cape Cod, in October 2006 (Table 1, Fig. 1). Whole fish were frozen at $-20^{\circ} \mathrm{C}$, thawed at the University of New Hampshire (UNH, Durham) and fin clips were removed for analysis. A collection of immature cod (36 to $47 \mathrm{~cm}$, age 2 to 4 ) was sampled from Casco Bay in April 2007 by bottom trawl and fin clips were taken from individuals before being released.

Genetic analyses. DNA was extracted with Qiagen DNeasy tissue kits (Qiagen) or standard phenol/chloroform procedures. A panel of 11 microsatellite markers (Gmo02 and Gmo132, Brooker et al. 1994; Gmo19, Gmo35, Gmo36 and Gmo37, Miller et al. 2000; PGmo32, PGmo34, PGmo38, PGmo56 and PGmo58, Jakobs- 


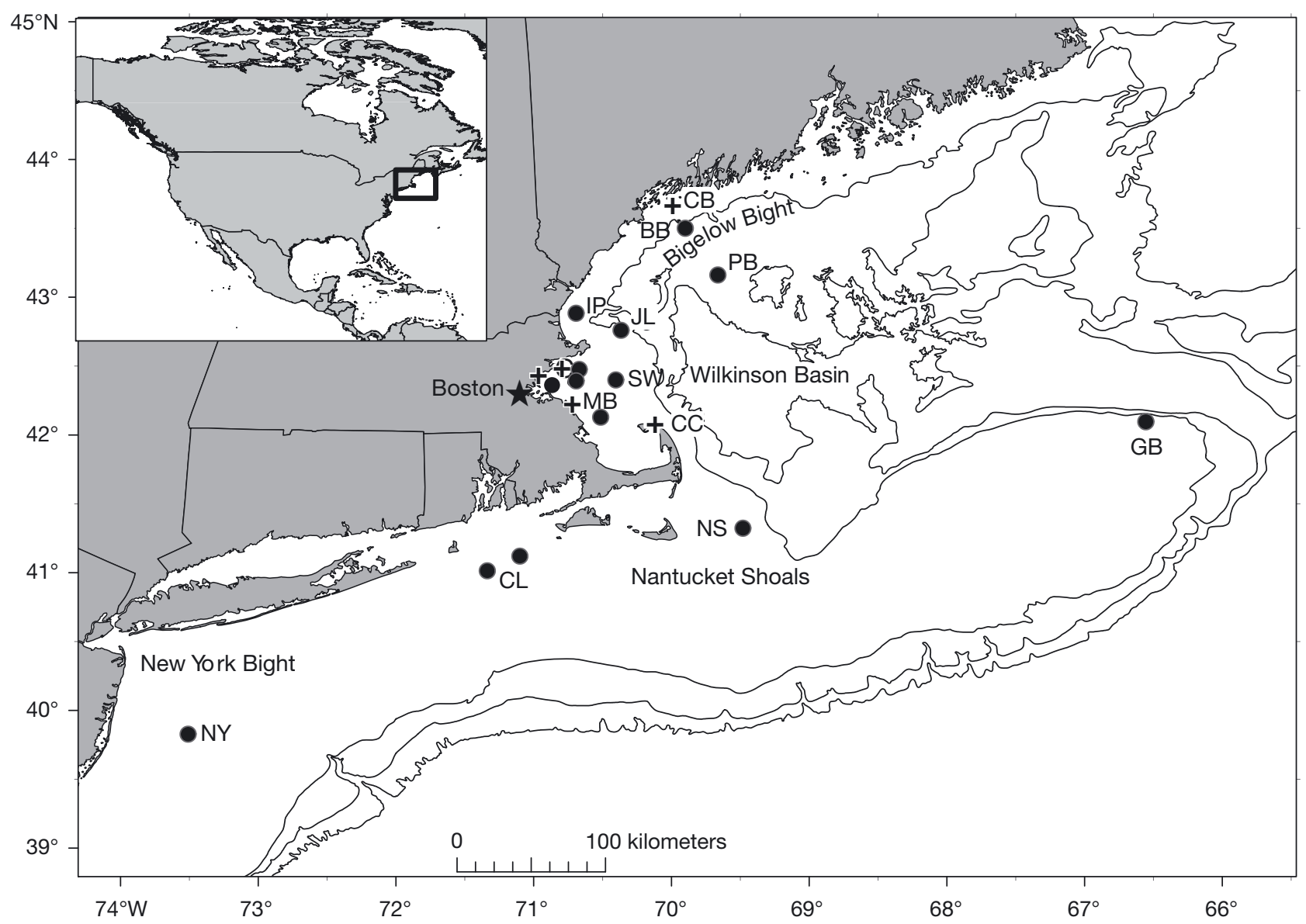

Fig. 1. Gadus morhua. Sample locations for (-) adult and (+) juvenile Atlantic cod collected in the present study. Abbreviated sample names are defined in Table 1

dóttir et al. 2006), the pantophysin I (PanI) locus (Pogson 2001), the AHR6 and ARNT8 SNP markers (Wirgin et al. 2007) and 3 novel SNP markers, ARNT1, CYP5 and Kras, were used. With the exception of the July 2008 Bigelow Bight samples and the juvenile samples, all samples were genotyped with the same suite of markers as follows: genotyping of microsatellites Gmo02, Gmo19, Gmo36, PGmo34, PGmo56, PGmo58 and the PanI locus were performed at UNH, and genotyping of microsatellites Gmo132, Gmo35, Gmo37, PGmo32, PGmo38 and development and analysis of the SNPs were performed at New York University School of Medicine (NYU). The 2008 Bigelow Bight and juvenile samples were genotyped entirely at UNH by means of 10 microsatellite loci and the PanI locus. To ensure consistency in the microsatellite allele scores for these samples relative to the remainder of the data set, a subset of samples ( $\mathrm{n}=123$ ) were genotyped at Gmo132, Gmo35, Gmo37, PGmo32 and PGmo38 in laboratories at both institutions and the microsatellite allele scores at UNH were calibrated to those of NYU. Similarity of genotypes in the 2 temporal Bigelow Bight samples (see
'Results') suggest that calibration issues were not a concern.

Microsatellite analysis was conducted using procedures in Wirgin et al. (2007) or in $12 \mu$ total volumes containing $2 \mu \mathrm{l}$ DNA template (50 to $200 \mathrm{ng}^{-1}$ ), $0.5 \mu \mathrm{M}$ of each primer, 1× GoTaq Flexi PCR Buffer (Promega), $0.2 \mathrm{mg} \mathrm{ml}^{-1}$ bovine serum albumin, $1 \mathrm{mM}$ $\mathrm{MgCl}_{2}, \quad 100 \mu \mathrm{M}$ deoxynucleotide triphosphates (dNTPs) and 0.2 U GoTaq Flexi DNA Polymerase (Promega). At UNH, the forward or reverse primer of each microsatellite was fluorescently labeled with FAM, NED or HEX, and amplification parameters followed those described in the literature for each primer set. PanI genotyping was conducted using the method of Stenvik et al. (2006a). Multiplex PCRs were conducted for loci with primers sharing common annealing temperatures (within $2^{\circ} \mathrm{C}$ ). PCR products were diluted (15 to 20×) and electrophoresed in an ABI3130 automated capillary sequencer (Applied Biosystems). Alleles were scored manually using PeakScanner v. 1.0 software (Applied Biosystems). At NYU, characterization of microsatellite genotypes was performed in a $\mathrm{CEQ}^{\mathrm{TM}} 8000$ capillary-based DNA sequencer (Beck- 
man Coulter). Multiplexed PCR reactions were diluted up to 1:3 with Sample Loading Solution (SLS; Beckman Coulter). Diluted PCR reactions $(0.5$ to $2 \mu \mathrm{l})$ were loaded onto 96-well plates along with $0.5 \mu$ l of CEQ DNA Size Standard-400 (Beckman Coulter) and $40 \mu \mathrm{l}$ of SLS and run with the FRAG 1 program (Beckman Coulter). MiCRO-CHECKER (van Oosterhout et al. 2004) was used to test for the presence of null alleles, errors due to microsatellite stuttering and large-allele dropout.

The 5' nuclease reaction with TaqMan probes was used to genotype SNPs with Real-Time PCR. Primer and probe combinations for the 3 new SNP loci are as follows. Ras primers: GAA CCA TTT TGT GGA CGA GTA TGA and GGG ACC AAG AGG TTA ATA TGA AGG T; Ras probes: VIC-CAA CCA TCG AGG TAA A and FAM-AAC CAT TGA GGT AAA GT. ARNT1 primers: CGC GTC AAA TAC AAC GAC TTG T and GGC CTA CAT AGC TTG ATA GTG ATA GCT; ARNT1 probes: FAM-TCC AGT TAA ACA ACC AAA A and VIC-CAA GTT AAA CAA CCA CAA. CYP5 primers: TTT GAG TGG CAC CCA TAG CA and CCA TTT CCT GGA CAG CTG AAG; CYP5 probes: FAM-TTG GTG ACA CGG CTT and VIC-TCT GTT GGT GAC AAG G. Amplifications occurred in an ABI 7300 Real-Time PCR instrument or in PTC-100 ${ }^{\mathrm{TM}}$ cyclers (MJ Research). Plates with amplicons from the PTC- $100^{\mathrm{TM}}$ cyclers were transferred after amplification to the ABI 7300 PCR instrument for allelic discrimination. Allele scoring was achieved with ABI Sequence Detection v. 2.1 software.

Statistical analyses. Descriptive statistics: Measures of diversity, including mean number of alleles, allelic richness, $F_{\mathrm{IS}}$ and observed and expected heterozygosities $\left(H_{\mathrm{o}}\right.$ and $\left.H_{\mathrm{e}}\right)$ were calculated with GDA (Lewis \& Zaykin 2001) for each locus and population sampled. Locus-specific $F_{\mathrm{ST}}$ values and Fisher's exact tests of allelic differentiation were calculated in GENEPOP v. 3.4 (Raymond \& Rousset 1995). We calculated the standardized measure of genetic differentiation $G_{\text {ST }}^{\prime}$ (Hedrick 2005) for each of the 3 types of markers (microsatellites, PanI and SNPs), by dividing the observed $F_{\mathrm{ST}}$ value by its theoretical maximum, $F_{\text {max }}$ using the program RECODE DATA v. 0.1 (Meirmans 2006). Because at least 2 of the markers used in this study, Gmo132 and PanI, have previously been shown to be under selection in other Atlantic cod populations, we performed selection tests for all loci using an $F_{\text {ST }}$ outlier approach (Beaumont \& Nichols 1996) in LositAN (Antao et al. 2008). Tests of deviations from Hardy-Weinberg equilibrium (HWE) and linkage disequilibrium (LD) per locus and population were conducted in GENEPOP by means of the Markov chain method with 10000 iterations and 10000 batches. Significance levels for multiple tests were adjusted to an $\alpha=0.05$ level with the standard Bonferroni method (Rice 1989).

Annual variation in genetic structure: Samples collected from the same spawning location and season in 2 separate years were examined for annual fluctuations in genetic variation using the $F_{\mathrm{ST}}$ estimator $\theta$, of Weir \& Cockerham (1984), produced in FSTAT 2.9.3 (Goudet 1995). Temporal stability was also assessed with a hierarchical analysis of molecular variance (AMOVA) conducted in ARLEQUIN 2.0 (Schneider et al. 2000) with 10000 permutations. This method partitions the genetic variation among sites and between years. For population genetic structure to be meaningful, the differences among sites must be significantly greater than the differences between years within the same sites (Waples 1998). In the absence of significant differentiation, yearly samples from the same sites were pooled for further analyses.

Population genetic structure: To test for genetic differences among adult and juvenile samples, pairwise allelic differentiation tests in GENEPOP and $F_{\mathrm{ST}}$ calculations in FSTAT were used. Significance was adjusted with the standard Bonferroni correction. $F_{\mathrm{ST}}$ values for the pooled data set were also used in a principal component analysis (PCA) using Genalex 6.1 (Peakall \& Smouse 2006) to visualize the clustering of populations. For adult cod samples, analyses were conducted initially with only the spawning populations and secondarily with the addition of the resting populations. A posteriori analysis of population clusters identified by $F_{\mathrm{ST}}$ and PCA was conducted with a hierarchical approach in AMOVA to compare genetic variation within and among clusters.

To evaluate an isolation by distance (IBD) model, we used Mantel's tests implemented in GENALEX to test for a correlation of genetic distance $\left(F_{\mathrm{ST}}\right)$ and shortest ocean distance between sample locations. IBD was evaluated across all spawning populations overall and within the identified clusters. For samples with identical geographic coordinates (spawning sites sampled in 2 different seasons), IBD analyses were conducted with the exclusion of one seasonal sample.

Genetic barriers were identified with the program BARRIER 2.2 (Manni et al. 2004). This approach uses the Monmonier algorithm to identify geographic areas associated with genetic discontinuities among spatially connected populations. We created BARRIER maps from the geographic coordinates of the adult sample locations. To facilitate comparison of seasonal samples within a spatial framework, sites with identical geographic coordinates (sites from which samples were collected from the same location in different seasons) were placed adjacent to one another in the map. We conducted the analyses using 2 genetic distances: (1) one with bootstrapping over 100 matrices of Nei's 
standard genetic distance $D$ (Nei 1987) calculated in the program MSA (Dieringer \& Schlötterer 2003); (2) the other with $16 F_{\mathrm{ST}}$ matrices for each of the loci separately. A combination of the 2 approaches enabled us to evaluate the strength of the barriers and contributions of the different markers.

Five-year temporal stability: To address the question of temporal stability of allelic frequencies over a longer period (2003 to 2008), we compared our results with those from our previous work (Wirgin et al. 2007) in which we genotyped spawning cod from Ipswich Bay ( $\mathrm{n}=48$ in both January and May 2003), the Great South Channel offshore of Chatham, Massachusetts $(\mathrm{n}=40$, November 2003), Stellwagen Bank ( $=27$, January 2005), northeast Georges Bank ( $\mathrm{n}=100$, February 2005) and resting (nonspawning) adults from western Long Island, New York $(\mathrm{n}=80$, January and February 2005). For this analysis, we used 8 of the 9 loci that were common to the 2 studies (Gmo02, Gmo132, Gmo35, Gmo36, Gmo37, PanI, AHR6 and ARNT1). Microsatellite data from 3 loci (Gmo02, Gmo132, Gmo36) were calibrated by reanalyzing a subset $(\mathrm{n}=35)$ of the samples from Wirgin et al. (2007) to correct for differences in electrophoresis platforms among years. Data from the remaining loci were easily compared between studies due to consistency in the analysis platforms and because scoring of the biallelic loci (SNPs and PanI) was not platform-dependent. A PCA was conducted with pairwise population $F_{\mathrm{ST}}$ values to visualize the genetic data. We used AMOVA to test for variation among temporal samples from the same locations.

Origin of juveniles: To determine the spawning population of origin of juvenile cod samples, pairwise pop- ulation $F_{\mathrm{ST}}$ values for the juvenile and pooled spawning adult samples were used in a PCA in GenAlEX. To determine whether juveniles could be assigned to their population of origin, mixture analysis was performed by means of the conditional maximum likelihood approach of ONCOR (Anderson et al. 2008). Confidence intervals (CIs) of mixture proportions were determined through 10000 bootstraps. The accuracy of the genetic stock identification was assessed through self-assignment of adult individuals to their respective populations by using the leave-one-out cross-validation test and through $100 \%$ fishery simulations of 50 individuals and 1000 simulations. These methods provide less biased predictions of accuracy than conventional parametric bootstrapping procedures (Anderson et al. 2008) and probably give more realistic estimates of the power of assignments.

\section{RESULTS}

\section{Descriptive statistics}

Multilocus genotypes were compiled for 1534 Atlantic cod adults by using 10 of the 11 microsatellites, the PanI locus and 5 SNP markers, and for 47 adults and 242 juveniles by using the 10 microsatellites and the PanI locus. Reliable genotypes could not be obtained for the PGmo56 microsatellite locus due to irregular scoring patterns and it was removed from further analyses. Descriptive statistics of the markers are shown in Table 2 and genetic diversity of the population samples is in Table 3. With the exception of PGmo-

Table 2. Gadus morhua. Number of alleles, allelic richness (AR), observed $\left(H_{\mathrm{o}}\right)$ and expected $\left(H_{\mathrm{e}}\right)$ heterozygosity, $F_{\mathrm{IS}}, F_{\mathrm{ST}}$ and allelic differentiation $\mathrm{p}$-values among adult and juvenile Atlantic cod for 16 genetic markers. Bold text indicates significance at the $\alpha=0.05$ level. - : not analysed

\begin{tabular}{|c|c|c|c|c|c|c|c|c|c|c|c|c|c|c|}
\hline \multirow{2}{*}{ Locus } & \multirow{2}{*}{\multicolumn{2}{|c|}{ Alleles AR }} & \multirow[b]{2}{*}{$H_{\mathrm{o}}$} & \multicolumn{4}{|c|}{ Adults } & \multirow[b]{2}{*}{ Alleles } & \multirow[b]{2}{*}{$\mathrm{AR}$} & \multirow[b]{2}{*}{$H_{\mathrm{o}}$} & \multicolumn{2}{|c|}{ Juveniles } & \multirow[b]{2}{*}{$F_{\mathrm{ST}}$} & \multirow[b]{2}{*}{$\mathrm{p}$} \\
\hline & & & & $H_{\mathrm{e}}$ & $F_{\mathrm{IS}}$ & $F_{\mathrm{ST}}$ & $\mathrm{p}$ & & & & $H_{\mathrm{e}}$ & $F_{\text {IS }}$ & & \\
\hline Gmo02 & 25 & 10.3 & 0.784 & 0.792 & 0.010 & 0.0001 & 0.3894 & 18 & 12.1 & 0.838 & 0.797 & -0.052 & -0.0021 & 0.8792 \\
\hline Gmo19 & 74 & 27.1 & 0.958 & 0.963 & 0.005 & 0.0003 & 0.0158 & 46 & 29.9 & 0.936 & 0.961 & 0.026 & -0.0005 & 0.1406 \\
\hline Gmo132 & 25 & 11.6 & 0.735 & 0.750 & 0.019 & 0.0327 & $<0.0001$ & 19 & 13.0 & 0.777 & 0.776 & -0.002 & 0.0408 & $<0.0001$ \\
\hline Gmo35 & 13 & 7.0 & 0.770 & 0.773 & 0.004 & 0.0011 & 0.2552 & 9 & 7.7 & 0.746 & 0.771 & 0.033 & 0.0004 & 0.0687 \\
\hline Gmo36 & 14 & 4.0 & 0.577 & 0.617 & 0.064 & 0.0021 & 0.0492 & 6 & 4.0 & 0.546 & 0.570 & 0.042 & 0.0186 & 0.0017 \\
\hline Gmo37 & 18 & 10.3 & 0.857 & 0.861 & 0.005 & 0.0005 & 0.1595 & 17 & 11.8 & 0.834 & 0.867 & 0.037 & 0.0033 & 0.1786 \\
\hline PGmo32 & 5 & 3.3 & 0.389 & 0.373 & -0.043 & -0.0023 & 0.9279 & 4 & 3.5 & 0.417 & 0.366 & -0.140 & -0.0006 & 0.4775 \\
\hline PGmo34 & 13 & 5.5 & 0.585 & 0.588 & 0.005 & 0.0037 & 0.0523 & 10 & 6.3 & 0.563 & 0.582 & 0.033 & -0.0080 & 0.9523 \\
\hline PGmo38 & 25 & 12.3 & 0.863 & 0.869 & 0.007 & 0.0016 & 0.1167 & 21 & 13.9 & 0.849 & 0.864 & 0.018 & 0.0009 & 0.1160 \\
\hline PGmo58 & 11 & 5.4 & 0.270 & 0.282 & 0.040 & 0.0022 & 0.0027 & 8 & 5.8 & 0.270 & 0.262 & -0.030 & 0.0023 & 0.1127 \\
\hline PanI & 2 & 1.9 & 0.082 & 0.083 & 0.016 & 0.0527 & $<0.0001$ & 2 & 2.0 & 0.083 & 0.080 & -0.041 & 0.1042 & $<0.0001$ \\
\hline AHR6 & 2 & 2.0 & 0.440 & 0.430 & -0.024 & 0.0009 & 0.2947 & - & - & - & - & - & - & - \\
\hline ARNT1 & 2 & 2.0 & 0.178 & 0.204 & 0.131 & 0.0023 & 0.0990 & - & - & - & - & - & - & - \\
\hline ARNT8 & 2 & 2.0 & 0.237 & 0.307 & 0.226 & -0.0007 & 0.3553 & - & - & - & - & - & - & - \\
\hline CYP5 & 2 & 2.0 & 0.332 & 0.330 & -0.007 & 0.0028 & 0.0842 & - & - & - & - & - & - & - \\
\hline Kras & 2 & 2.0 & 0.301 & 0.313 & 0.039 & -0.0003 & 0.4367 & - & - & - & - & - & - & - \\
\hline Overall & 14.7 & 6.8 & 0.523 & 0.533 & 0.020 & 0.0044 & $<0.0001$ & 14.5 & 10.0 & 0.624 & 0.627 & 0.005 & 0.0071 & $<0.0001$ \\
\hline
\end{tabular}


38, the microsatellite markers of Jakobsdóttir et al. (2006) had substantially lower heterozygosities than did the markers used in our previous study of Atlantic cod (Wirgin et al. 2007). Heterozygosities for Gmo02, Gmo19, Gmo132, Gmo35, Gmo36 and Gmo37 were similar to the values reported by Wirgin et al. (2007). Numbers of alleles across all populations ranged from 4 to 74 for the microsatellite loci. Heterozygosity and allelic diversity were similar across spawning popula-

Table 3. Gadus morhua. Genetic diversity of adult and juvenile Atlantic cod samples. Column values are means across 16 markers for number of alleles, allelic richness $(\mathrm{AR})$, observed $\left(H_{\mathrm{o}}\right)$ and expected $\left(H_{\mathrm{e}}\right)$ heterozygosity, $F_{\mathrm{IS}}$ values, and $\mathrm{PanI}^{\mathrm{A}}$ allele frequencies. Abbreviated sample names are defined in Table 1 and sample size is indicated by $\mathrm{n}$

\begin{tabular}{|lrrrcrrr|}
\hline Population & $\mathrm{n}$ & Alleles & AR & $H_{\mathrm{o}}$ & $H_{\mathrm{e}}$ & \multicolumn{1}{c}{$F_{\mathrm{IS}}$} & PanI $^{\mathrm{A}}$ \\
\hline Adults & & & & & & & \\
BBS & 117 & 9.6 & 6.7 & 0.527 & 0.555 & 0.051 & 0.132 \\
IPS & 200 & 10.6 & 6.9 & 0.548 & 0.545 & -0.007 & 0.103 \\
IPW & 31 & 7.0 & 6.7 & 0.486 & 0.514 & 0.055 & 0.016 \\
MBW & 217 & 10.7 & 6.8 & 0.516 & 0.528 & 0.022 & 0.021 \\
MBS & 85 & 8.6 & 6.6 & 0.539 & 0.547 & 0.013 & 0.129 \\
PBS & 70 & 8.8 & 6.7 & 0.552 & 0.543 & -0.015 & 0.100 \\
JLW & 73 & 8.7 & 6.7 & 0.492 & 0.525 & 0.062 & 0.014 \\
SWS & 115 & 9.1 & 6.7 & 0.511 & 0.521 & 0.019 & 0.009 \\
GBW & 197 & 10.8 & 6.8 & 0.525 & 0.537 & 0.021 & 0.020 \\
NTW & 109 & 9.2 & 6.6 & 0.530 & 0.514 & -0.030 & 0.000 \\
CLW & 158 & 10.3 & 6.6 & 0.507 & 0.514 & 0.014 & 0.006 \\
CLS & 118 & 9.4 & 6.7 & 0.508 & 0.526 & 0.033 & 0.000 \\
NYS & 47 & 8.4 & 7.2 & 0.535 & 0.541 & 0.012 & 0.032 \\
NYW & 44 & 7.9 & 6.8 & 0.511 & 0.526 & 0.029 & 0.023 \\
Overall & 113 & 9.2 & 6.8 & 0.520 & 0.531 & 0.020 & 0.043 \\
Juveniles & & & & & & & \\
CBSJ & 45 & 10.5 & 10.4 & 0.605 & 0.635 & 0.047 & 0.000 \\
MBWJ & 82 & 10.7 & 9.4 & 0.642 & 0.632 & -0.017 & 0.122 \\
MBSJ & 46 & 10.8 & 10.7 & 0.623 & 0.622 & -0.003 & 0.000 \\
CCWJ & 69 & 10.5 & 9.4 & 0.613 & 0.608 & -0.007 & 0.000 \\
Overall & 61 & 10.6 & 10.0 & 0.621 & 0.624 & 0.005 & 0.031 \\
\hline
\end{tabular}

tions, and slightly higher among juvenile samples. PanI $^{\mathrm{A}}$ allele frequencies ranged from 0 to 0.132 (Table 3).

For the adult population samples, $F_{\mathrm{ST}}$ values ranged from -0.0023 to 0.0527 per locus, and were highly significant overall with a global $F_{\mathrm{ST}}$ of $0.0044(\mathrm{p}<0.0001)$ (Table 2). The highest levels of differentiation were observed at Gmo132 and PanI, with $F_{\mathrm{ST}}$ values of 0.0327 and 0.0527 , respectively, and highly significant $(p<0.0001)$ allelic differentiation across all samples by the exact test. Consistent with previous studies (Pogson 2001, Nielsen et al. 2006), the results of the $F_{\mathrm{ST}}$ outlier test indicated that Gmo132 and PanI were candidates for positive selection (Fig. 2). All other markers were within neutral expectations. Among the neutral loci, Gmo19, Gmo36 and PGmo58 showed significant differentiation $\left(0.0003<F_{\mathrm{ST}}<\right.$ 0.0022). Differentiation for the neutral loci alone was also significant (global $F_{\mathrm{ST}}=0.0011$; allelic differentiation, $\mathrm{p}<$ $0.0001) . G_{\text {ST }}^{\prime}$ values were 0.015 for the microsatellites, 0.061 for PanI and 0.001 for the SNPs.

Differentiation among juvenile samples was highly significant $(\mathrm{p}<0.0001)$ across all loci $\left(F_{\mathrm{ST}}=0.0071\right)$ and for the neutral loci alone $\left(F_{\mathrm{ST}}=0.0014\right)$. As with the adult samples, Gmo132 and PanI displayed the highest per locus $F_{\mathrm{ST}}$ values $(0.0408$ and 0.1042 , respectively) and exhibited highly significant allelic differentiation (Table 2). Differentiation among juvenile samples was

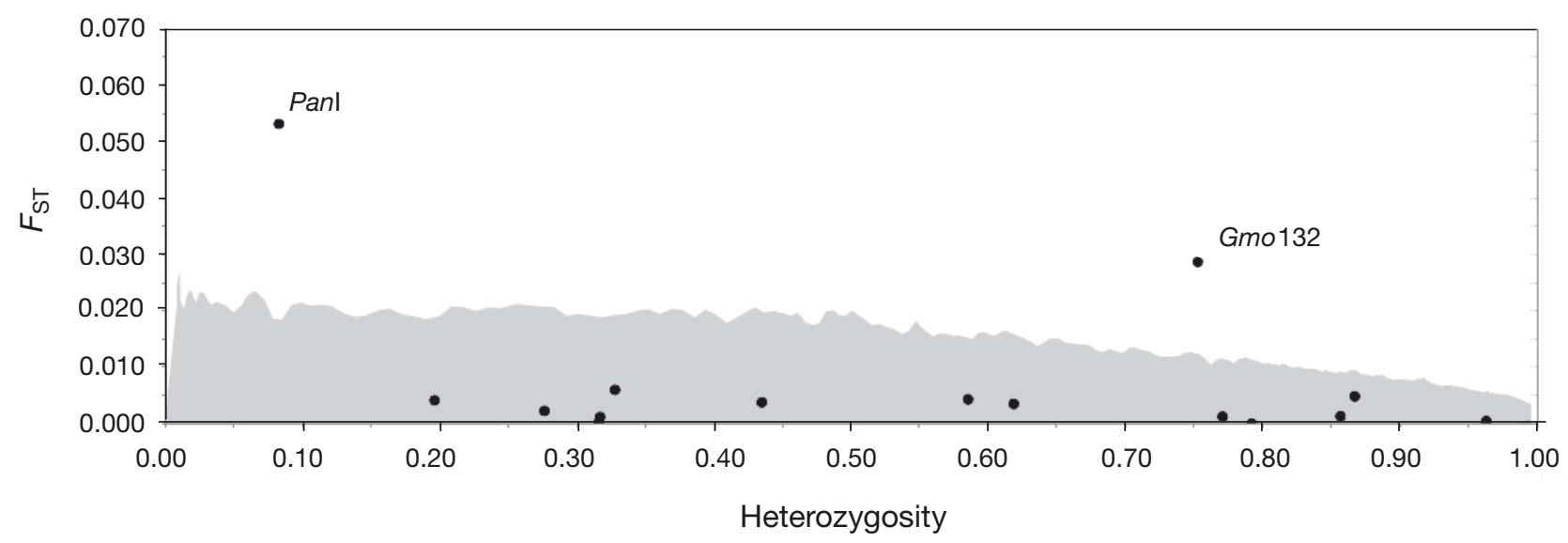

Fig. 2. Gadus morhua. Selection test for 16 genetic markers; $F_{\mathrm{ST}}$ is plotted as a function of heterozygosity. Markers located within the light gray area are within the $95 \%$ CI for neutral markers; markers above this area are candidates for positive selection 
greater than among adult samples, driven by the PanI locus for which the $F_{\mathrm{ST}}$ value for the juvenile samples was almost double that of the adult samples. Among the neutral loci, only Gmo36 showed significant differentiation $\left(F_{\mathrm{ST}}=0.0186, \mathrm{p}=0.0017\right) . G_{\mathrm{ST}}^{\prime}$ values for the juvenile samples were 0.019 for the microsatellites and 0.112 for PanI (the SNPs were not used in the analysis of juvenile samples).

All adult samples conformed to HWE except those for Cox Ledge winter at the ARNT8 locus (1 of 224 comparisons), which exhibited a significant heterozygote deficiency $(p=0.0001)$. The juvenile samples were all in HWE except those from the Massachusetts Bay collection from October 2007 at Gmo37 (1 of 55 comparisons), which had a significant heterozygote deficiency $(p<0.0001)$. MiCRO-CHECKER software detected no evidence of stuttering or large-allele drop out, but did detect the possible presence of null alleles within the adult samples from Massachusetts Bay winter (Gmo36), Georges Bank (Gmo36 and PGmo38), Cox Ledge winter (PGmo38) and the Bigelow Bight (Gmo02). Because these populations conformed to HWE at these loci, this possibility was not considered in further analyses. LD was detected between the $A R N T 1$ and ARNT8 markers for the adult samples (1 of 120 comparisons, $\mathrm{p}<0.0001$ ) (data not shown); however, no significant LD was detected for any sample when each of the adult populations was considered separately. LD was not detected among the juvenile samples.

\section{Annual variation in genetic structure}

Adult samples collected from the same site and season in 2 separate years were found to be genetically homogenous by both $F_{\mathrm{ST}}$ and AMOVA. Of the 6 comparisons, 4 had negative $F_{\mathrm{ST}}$ values (data not shown) and the 2 comparisons from Ipswich Bay and Massachusetts Bay spring had nonsignificant but positive $F_{\mathrm{ST}}$ values of 0.0006 and 0.0075 , respectively. The Massachusetts Bay spring comparisons may have suffered from lack of precision due to low sample size of 1 of the 2 yearly samples $(\mathrm{n}=$ 36 for the April 2006 samples; a minimum of 50 individuals per sample is recommended, Ruzzante et al. 1996a). Pairwise $F_{\mathrm{ST}}$ comparisons of these samples using only neutral markers produced all negative values (data not shown). AMOVA results also demonstrated no significant variation between years for all loci as well as the neutral markers alone and indicated that annual fluctuations in genetic variation were minimal compared with the differences among sites (Table 4). While the differences among sites were significant for the neutral markers alone, the $F_{\mathrm{CT}}$ value was very small $(0.001)$ and the pattern was much stronger when all loci were used $\left(F_{\mathrm{CT}}=0.0044\right)$. Locus-by-locus AMOVA confirmed that this pattern of variance was largely driven by the 2 non-neutral loci (see Table S1 in the Supplement at www.int-res.com/articles/suppl/m410p177_ supp.pdf). These results indicated stability in the genetic structure from year to year, and the replicate samples from the $2 \mathrm{yr}$ of the study were pooled for further analyses.

\section{Genetic structure of spawning populations}

Since our primary objective was to characterize the genetic structure of spawning populations of Atlantic cod, we first considered only the samples from sites at which spawning individuals were collected $(n=10$ spawning sites, including spawning, spent and ripe condition categories described in Table 1). Pairwise $F_{\mathrm{ST}}$ comparisons of the spawning populations yielded 16 of 45 significant values, ranging from 0.0029 to 0.0156 , and 26 of 45 significant tests of allelic differentiation ( $\mathrm{p} \leq$ 0.0011, following Bonferroni adjustment) (Table 5). Significant differentiation was primarily due to divergence between the spring spawning populations from the inshore Gulf of Maine (Bigelow Bight, Ipswich Bay and Massachusetts Bay) and the majority of the remaining spawning sites, and divergence between the Georges Bank sample and the southern New England samples. Employing the less conservative criterion of $\mathrm{p} \leq 0.05$ yielded another 18 significant comparisons for $F_{\mathrm{ST}}$ values ranging from 0.0005 to 0.0076 . Overall, 35

Table 4. Gadus morhua. Analysis of molecular variance (AMOVA) of genetic variation among sites, years and samples for 6 sites sampled in 2 yr using all loci and neutral markers only (PanI and Gmo132 are excluded). Bold text indicates significance $(\mathrm{p}<0.05)$

\begin{tabular}{|lrcrrrr|}
\hline $\begin{array}{l}\text { Source of } \\
\text { variation }\end{array}$ & df & $\begin{array}{c}\text { Variance } \\
\text { components }\end{array}$ & $\begin{array}{c}\% \\
\text { variation }\end{array}$ & $\begin{array}{l}\text { Fixation } \\
\text { indices }\end{array}$ & $\mathrm{p}$ \\
\hline All loci & & & & & & \\
Among sites & 5 & 0.0153 & 0.44 & CT 0.0044 & $<\mathbf{0 . 0 0 0 1}$ \\
Among years & 6 & 0.0015 & 0.04 & SC 0.0004 & 0.2638 \\
Within samples & 1850 & 3.4503 & 99.52 & ST 0.0048 & $<\mathbf{0 . 0 0 0 1}$ \\
Total & 1861 & 3.4670 & & & & \\
Neutral markers only & & & & & \\
Among sites & 5 & 0.0032 & 0.10 & CT 0.0010 & $\mathbf{0 . 0 3 4 1}$ \\
Among years & 6 & -0.0028 & -0.09 & SC -0.0009 & 0.9259 \\
Within samples & 1850 & 3.0320 & 99.99 & ST 0.0001 & 0.5202 \\
Total & 1861 & 3.0323 & & & & \\
\hline
\end{tabular}


Table 5. Gadus morhua. Population differentiation of spawning populations of Atlantic cod. Allelic differentiation p-values are shown above the diagonal break; pairwise population $F_{\text {ST }}$ values with p-values in parentheses are shown below the diagonal. Abbreviated sample names are defined in Table 1. Bold text indicates significance following standard Bonferroni correction ( $\mathrm{p} \leq$ 0.0011 ). Significance at the 0.05 and 0.01 levels are indicated by ${ }^{*}$ and ${ }^{* *}$, respectively

\begin{tabular}{|c|c|c|c|c|c|c|c|c|c|c|}
\hline & BBS & IPS & JLW & MBW & MBS & SWS & GBW & NTW & CLW & CLS \\
\hline BBS & & 0.1810 & 0.0002 & $<0.0001$ & 0.7559 & $<0.0001$ & $<0.0001$ & $<0.0001$ & $<0.0001$ & $<0.0001$ \\
\hline IPS & $\begin{array}{c}0.0007 \\
(0.0367)^{*}\end{array}$ & & 0.0006 & $<0.0001$ & 0.7593 & $<0.0001$ & 0.0001 & $<0.0001$ & $<0.0001$ & $<0.0001$ \\
\hline JLW & $\begin{array}{l}0.0063 \\
(0.0078)^{* *}\end{array}$ & $\begin{array}{l}0.0067 \\
(0.0044)^{* *}\end{array}$ & & 0.6299 & 0.0001 & 0.1640 & 0.2598 & $0.0074^{* *}$ & 0.7171 & $0.0193^{*}$ \\
\hline MBW & $\begin{array}{c}0.0054 \\
(0.0011)\end{array}$ & $\begin{array}{c}0.0071 \\
(0.0011)\end{array}$ & $\begin{array}{c}0.0016 \\
(0.2989)\end{array}$ & & $<0.0001$ & 0.1731 & $<0.0001$ & $0.0349^{*}$ & 0.4910 & 0.3408 \\
\hline MBS & $\begin{array}{c}-0.0005 \\
(0.4856)\end{array}$ & $\begin{array}{c}-0.0017 \\
(0.4256)\end{array}$ & $\begin{array}{l}0.0076 \\
(0.0156)^{*}\end{array}$ & $\begin{array}{c}0.0093 \\
(0.0011)\end{array}$ & & $<0.0001$ & $<0.0001$ & $<0.0001$ & $<0.0001$ & $<0.0001$ \\
\hline SWS & $\begin{array}{l}0.0065 \\
(0.0022)^{* *}\end{array}$ & $\begin{array}{c}0.0071 \\
(0.0022)^{* *}\end{array}$ & $\begin{array}{c}0.0026 \\
(0.3300)\end{array}$ & $\begin{array}{c}0.0004 \\
(0.0778)\end{array}$ & $\begin{array}{c}0.0080 \\
(0.0011)\end{array}$ & & 0.2046 & $0.0121^{*}$ & $0.0369^{*}$ & $0.0054^{* *}$ \\
\hline GBW & $\begin{array}{l}0.0017 \\
(0.0044)^{* *}\end{array}$ & $\begin{array}{l}0.0025 \\
(0.0056)^{* *}\end{array}$ & $\begin{array}{c}0.0020 \\
(0.0456)^{*}\end{array}$ & $\begin{array}{c}0.0018 \\
(0.0167)^{*}\end{array}$ & $\begin{array}{l}0.0036 \\
(0.0056)^{* *}\end{array}$ & $\begin{array}{c}0.0026 \\
(0.1044)\end{array}$ & & $<0.0001$ & $<0.0001$ & $<0.0001$ \\
\hline NTW & $\begin{array}{c}0.0107 \\
(0.0011)\end{array}$ & $\begin{array}{c}0.0097 \\
(0.0011)\end{array}$ & $\begin{array}{c}0.0039 \\
(0.0067)^{* *}\end{array}$ & $\begin{array}{c}0.0005 \\
(0.0244)^{*}\end{array}$ & $\begin{array}{c}0.0138 \\
(0.0011)\end{array}$ & $\begin{array}{c}0.0012 \\
(0.0067)^{* *}\end{array}$ & $\begin{array}{c}0.0036 \\
(0.0011)\end{array}$ & & 0.0562 & 0.0010 \\
\hline CLW & $\begin{array}{c}0.0078 \\
(0.0011)\end{array}$ & $\begin{array}{c}0.0090 \\
(0.0011)\end{array}$ & $\begin{array}{c}0.0009 \\
(0.6544)\end{array}$ & $\begin{array}{c}-0.0005 \\
(0.4133)\end{array}$ & $\begin{array}{c}0.0109 \\
(0.0011)\end{array}$ & $\begin{array}{c}0.0016 \\
(0.0178)^{*}\end{array}$ & $\begin{array}{c}0.0029 \\
(0.0011)\end{array}$ & $\begin{array}{c}0.0005 \\
(0.0267)^{*}\end{array}$ & & 0.4156 \\
\hline CLS & $\begin{array}{c}0.0097 \\
(0.0011)\end{array}$ & $\begin{array}{c}0.0124 \\
(0.0011)\end{array}$ & $\begin{array}{c}0.0061 \\
(0.0533)\end{array}$ & $\begin{array}{c}0.0007 \\
(0.4200)\end{array}$ & $\begin{array}{c}0.0156 \\
(0.0011)\end{array}$ & $\begin{array}{c}0.0047 \\
(0.0156)^{*}\end{array}$ & $\begin{array}{c}0.0056 \\
(0.0011)\end{array}$ & $\begin{array}{l}0.0036 \\
(0.0033)^{* *}\end{array}$ & $\begin{array}{c}0.0014 \\
(0.7378)\end{array}$ & \\
\hline
\end{tabular}

of 45 comparisons were significant by one or both differentiation methods at the $\mathrm{p} \leq 0.05$ level (not corrected). When the selected loci PanI and Gmo132 were excluded from the analyses, overall differentiation among sites was evident using the neutral markers alone, but was much weaker (data not shown).

Principal component analysis of the $F_{\mathrm{ST}}$ values from the spawning samples identified 2 main clusters (Fig. 3A): one comprising the spring spawning coastal Gulf of Maine populations of Bigelow Bight, Ipswich Bay and Massachusetts Bay and another cluster comprising spring spawners on Stellwagen Bank, winter spawners on Jeffrey's Ledge and Massachusetts Bay, and southern aggregations on Nantucket Shoals and Cox Ledge. Cod spawning on Georges Bank fell intermediately between these 2 clusters as they were distinct from the southern sites of Cox Ledge and Nantucket Shoals, but were only somewhat differentiated from the inshore Gulf of Maine populations in both winter and spring and similar to the offshore Gulf of Maine populations on Stellwagen Bank and Jeffreys Ledge.

A posterior analysis of hierarchical structure of the population clusters identified by $F_{\mathrm{ST}}$ and PCA gave support to these genetic groupings when all loci were included in the analysis (Table 6). Although the majority of the variation was attributable to differences within samples, the remaining variation was due primarily to differences among clusters. The percent variation $(0.95 \%)$ and fixation index $\left(F_{\mathrm{CT}}=0.0095\right)$ were much larger among than within clusters $\left(0.03 \%, F_{\mathrm{SC}}=\right.$
0.0003). This pattern was not evident when PanI and Gmo132 were excluded from the analysis (see Table S1 in the Supplement for locus-by-locus AMOVA). Mantel tests for correlation of geographic and genetic distances were all nonsignificant ( $p>0.05)$, even when samples with identical geographic locations were excluded. Similarly, no IBD was detected within the clusters identified by $F_{\mathrm{ST}}$ and PCA.

BARRIER analysis identified genetic discontinuities that were largely consistent using both distance methods, Nei's $D$ and $F_{\mathrm{ST}}$. The first-order barrier corresponded with the separation of the spring spawning coastal GOM population of Bigelow Bight, Ipswich Bay and Massachusetts Bay from the offshore and winter spawning GOM samples, with 72 to $82 \%$ bootstrap support from Nei's $D$ and support from 5 to 7 of 16 single locus $F_{\mathrm{ST}}$ matrices (the support for the boundaries between each pair of populations along this barrier varied slightly). The continuation of this first-order barrier separated the spring spawning coastal GOM cod samples from the Georges Bank samples and was supported by $49 \%$ bootstrapping and 5 loci. Second- and third-order barriers were identified between the Cox Ledge spring samples and the Nantucket and Cox Ledge winter samples and between Georges Bank and Nantucket and the offshore GOM. These lesser barriers were supported by 18 to $43 \%$ bootstrapping and only 1 to 5 loci.

The results of our above analyses are synthesized in Fig. 4 , in which we demonstrate the 3 primary genetic 

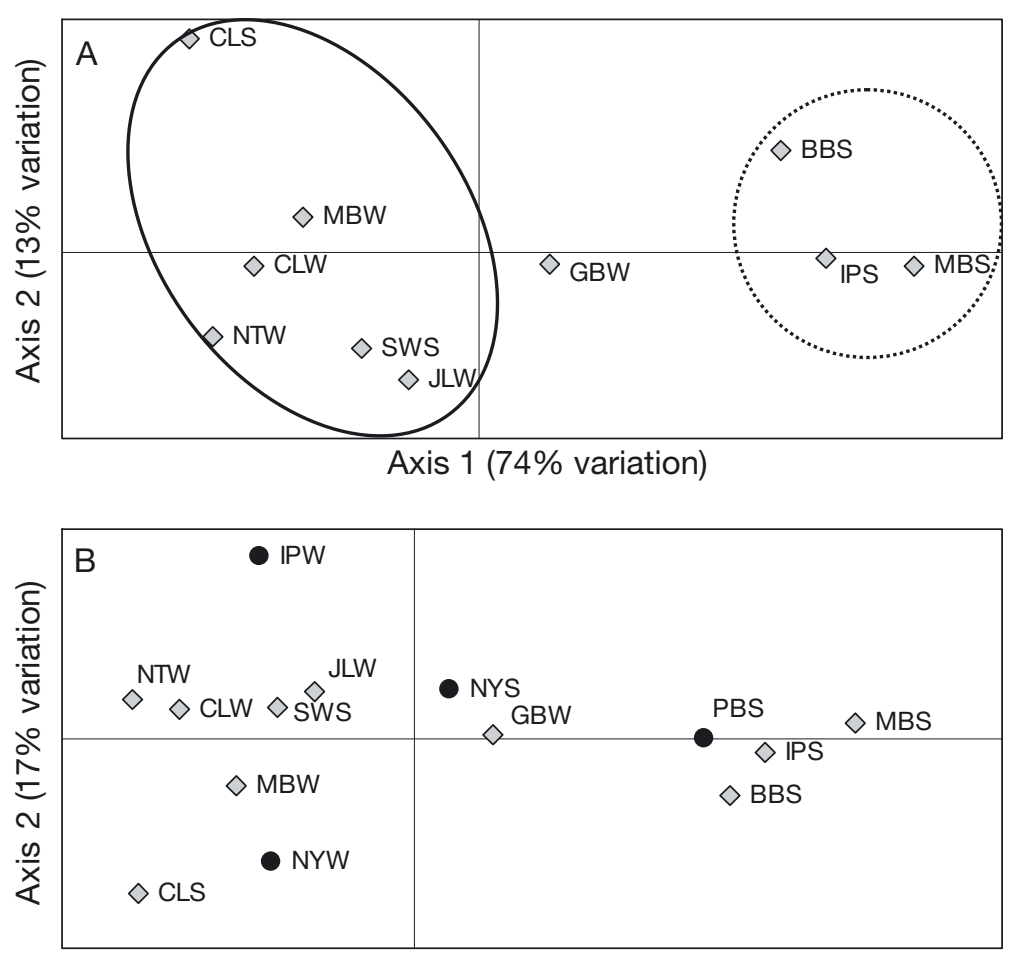

Axis 1 (58\% variation)

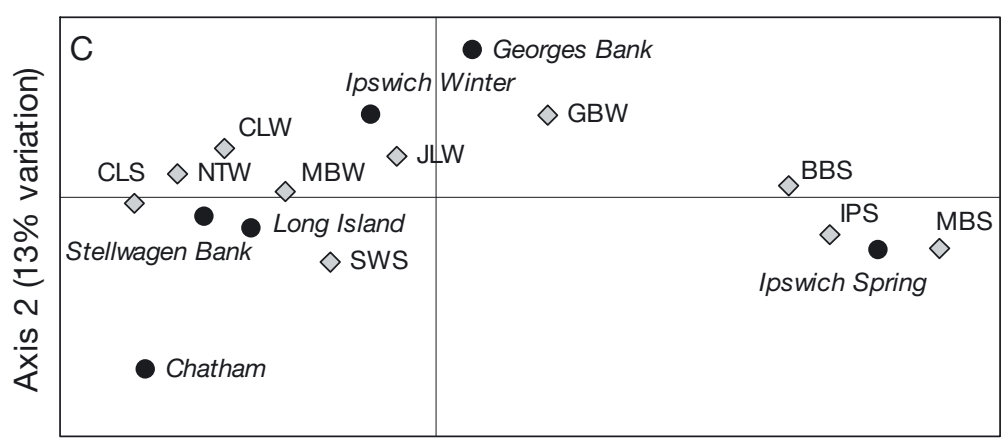

Axis 1 (73\% variation)

Fig. 3. Gadus morhua. Principal component analyses of pairwise population $F_{\mathrm{ST}}$ values of Atlantic cod samples. (A) Comparison of ( $\diamond$ ) spawning samples; circles surround genetically similar populations. (B) Comparison of $(\diamond)$ spawning and $(\bullet)$ resting samples. (C) Comparison of $(\diamond)$ spawning populations of the present study and (-) those sampled in Wirgin et al. (2007), labels in italics. Abbreviated sample names are defined in Table 1. Percent values refer to the percentage of variation explained by each axis

groupings of Atlantic cod: a northern spring complex spawns within coastal Gulf of Maine waters in the spring, a southern complex spawns in different inshore and offshore locations and seasons within the Gulf of Maine and in southern waters, and a Georges Bank population, which maintains some connectivity with populations spawning in the Gulf of Maine, especially its offshore spawning sites, but less connectivity with spawning aggregations south of Cape Cod. The $F_{\text {ST }}$ values between the complexes are 0.0085 between the northern spring and southern complexes, 0.0028 between the northern spring complex and Georges Bank and 0.0025 between the southern complex and Georges Bank.

The majority of variation among the populations could be explained by the PanI locus and 2 alleles at Gmo132. The northern spring complex was characterized by higher allelic frequencies of $P_{a n I}{ }^{\mathrm{A}}$ $(>0.100)$ in comparison with the southern complex that was nearly fixed for the $\operatorname{PanI}^{\mathrm{B}}$ allele. The southern complex also exhibited higher frequencies of the Gmo132 135 bp allele, while higher frequencies of the $117 \mathrm{bp}$ allele were found in northern spring complex cod. Georges Bank cod were heterogeneous between the complexes and exhibited similar Gmo132 allelic frequencies to the northern spring complex but near fixation for the $\operatorname{PanI}^{\mathrm{B}}$ allele (Fig. 5).

\section{Comparison of spawning and resting adult samples}

When the resting adult cod samples from Platts Bank, Ipswich Bay winter and the New York Bight were added to the analyses, they clustered primarily within 1 of the 2 spawning complexes (Fig. 3B). The Platts Bank summer adults clustered within the northern spring complex. New York Bight spring and winter samples clustered within the southern complex, although the spring sample was also similar to the Georges Bank samples. The Ipswich Bay winter adults clustered within the southern complex based on variation along the first axis, but exhibited a large displacement along the second axis. Variation along this second axis was approximately one-third that of the first axis and may not represent a significant population difference. Furthermore, this result may have been affected by a low sample size $(n=31)$.

\section{Five-year temporal stability of genetic structure}

Comparative analysis with the data set of Wirgin et al. (2007) showed stability in the population structure from 2003 to 2008. AMOVA detected no significant 
variation between samples collected from the same sites in different years (see Tables $7 \&$ S1). By PCA, the 2003 Ipswich Bay spring spawning sample clustered with the spring coastal GOM samples of this study (northern spring complex, Fig. 3C; pairwise population
$F_{\text {ST }}$ values are provided in Table S2). The Ipswich Bay winter, Chatham, Stellwagen Bank and Long Island samples clustered with the southern complex. The Georges Bank samples were very similar between the 2 studies and clustered together with a placement intermediate to the 2 complexes.
Table 6. Gadus morhua. Analysis of molecular variance (AMOVA) of genetic variation between the spawning complexes (see 'Results - Genetic structure of spawning populations' and Fig. 4), within the complexes and within samples of adult Atlantic cod using all loci and neutral markers only (PanI and Gmo132 are excluded)

\begin{tabular}{|lccccc|}
\hline $\begin{array}{l}\text { Source of } \\
\text { variation }\end{array}$ & df & $\begin{array}{c}\text { Variance } \\
\text { components }\end{array}$ & $\begin{array}{c}\% \\
\text { variation }\end{array}$ & $\begin{array}{c}\text { Fixation } \\
\text { indices }\end{array}$ \\
\hline All loci & & & & & \\
Among complexes & 1 & 0.0341 & 0.95 & CT & 0.0095 \\
Among samples within complexes & 7 & 0.0011 & 0.03 & SC & 0.0003 \\
Within samples & 2375 & 3.5495 & 99.02 & ST & 0.0098 \\
Total & 2383 & 3.5847 & & & \\
Neutral markers only & & & & & \\
Among complexes & 1 & -0.0025 & -0.08 & CT -0.0008 \\
Among samples within complexes & 7 & 0.0017 & 0.05 & SC & 0.0005 \\
Within samples & 2375 & 3.1628 & 100.02 & ST -0.0002 \\
Total & 2383 & 3.1621 & & & \\
\hline
\end{tabular}

\section{Population origin of juveniles}

Pairwise $F_{\mathrm{ST}}(0.0070$ to 0.0184$)$ and allelic differentiation tests detected significant variation among the 5 juvenile cod samples from the 4 sites and 2 seasons (Table 8). The Massachusetts Bay juveniles from October 2007 exhibited highly significant differentiation from the other juvenile samples, except a sample from the same season and location made in the previous year; the 2 October Massachusetts Bay collections were pooled in further analyses. Using the less conservative criteria $(\mathrm{p} \leq 0.05)$, differentiation was also

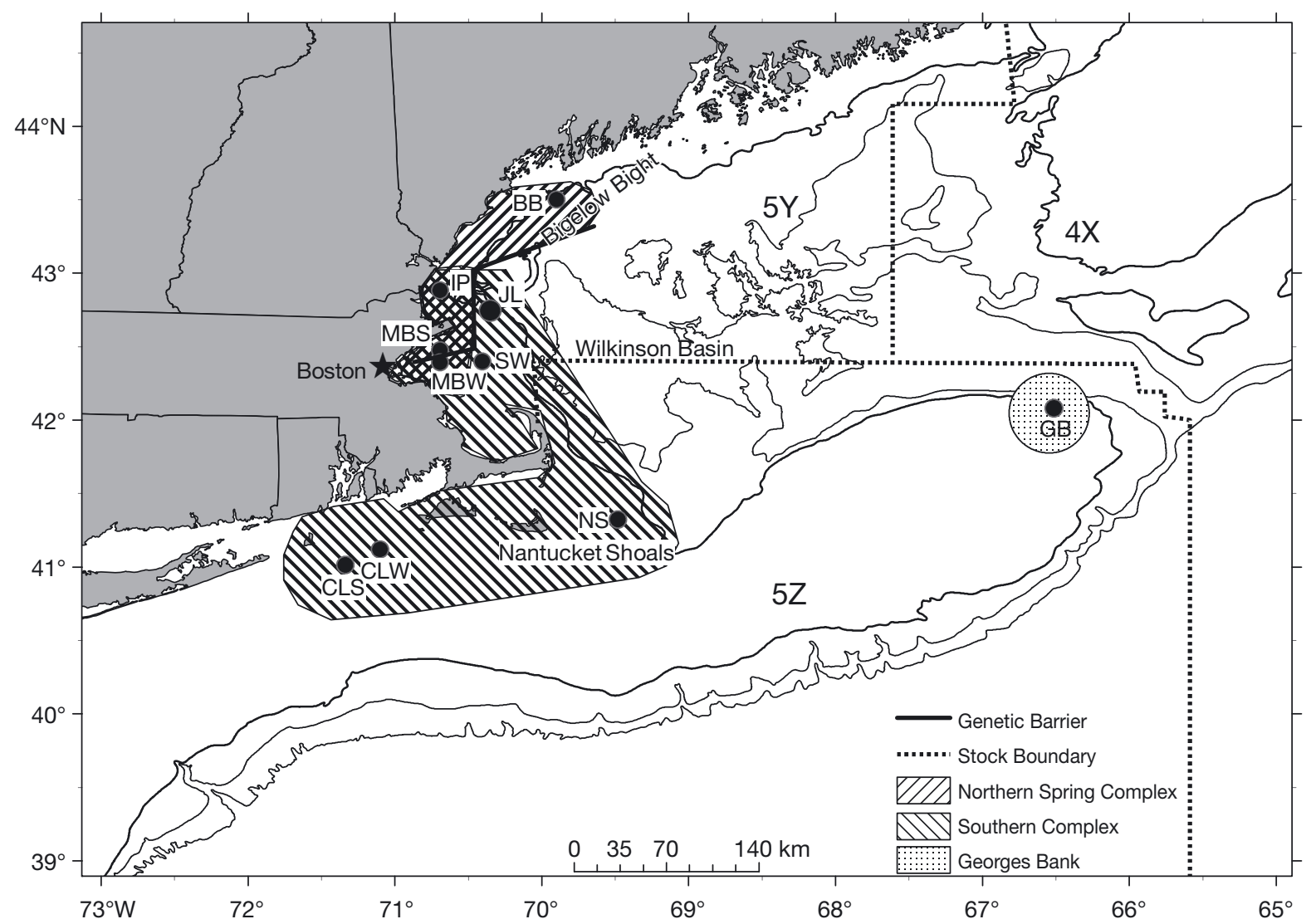

Fig. 4. Gadus morhua. Population structure of Atlantic cod spawning in US waters in relation to stock boundaries, 4X: Scotian Shelf; 5Y: Gulf of Maine; 5Z: Georges Bank. Three genetically similar population complexes and the first-order genetic barrier (see 'Results - Genetic structure of spawning populations' for explanation) are shown. Abbreviated sample names are defined in Table 1 


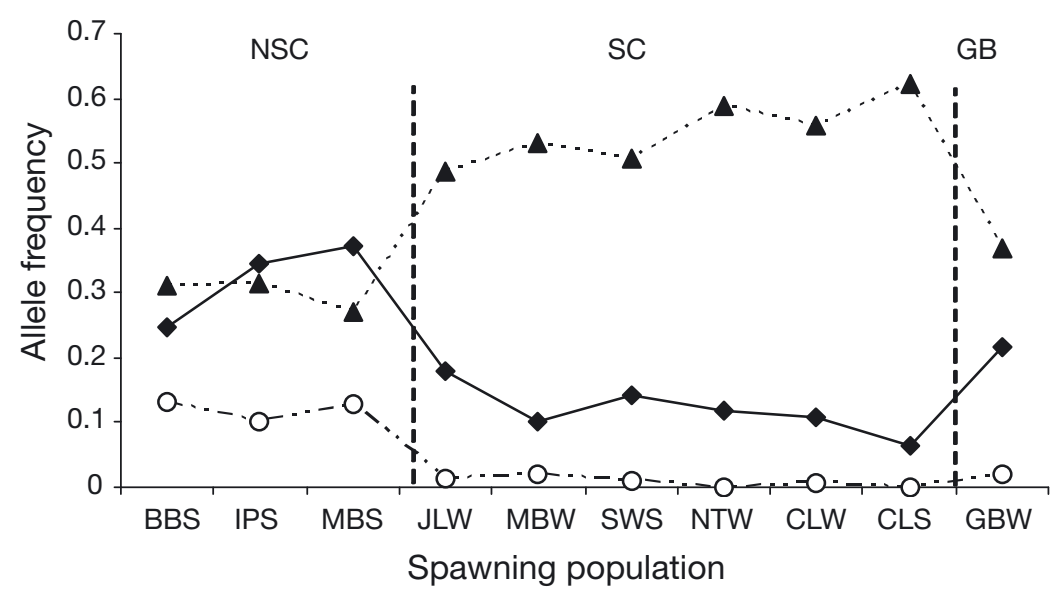

Fig. 5. Gadus morhua. Frequencies of the $(\diamond)$ Gmo132 (117 bp) allele, ( $(\Delta)$ Gmo132 (135 bp) allele and (O) PanI ${ }^{\mathrm{A}}$ allele of spawning Atlantic cod samples in the northern spring complex (NSC), southern complex (SC) and Georges Bank (GB). Abbreviated sample names are defined in Table 1

Table 7. Gadus morhua. Analysis of molecular variance (AMOVA) of genetic variation among sites, years and samples for 3 populations (IPS, IPW, GBW; see Table 1 for abbreviation definitions) compared between the present study and Wirgin et al. (2007). Bold text indicates significance $(p<0.05)$

\begin{tabular}{|lccccr|}
\hline $\begin{array}{l}\text { Source of } \\
\text { variation }\end{array}$ & df & $\begin{array}{c}\text { Variance } \\
\text { components }\end{array}$ & $\begin{array}{c}\% \\
\text { variation }\end{array}$ & \multicolumn{1}{c|}{$\begin{array}{c}\text { Fixation } \\
\text { indices }\end{array}$} & $\mathrm{p}$ \\
\hline Among sites & 2 & 0.0150 & 0.65 & CT 0.0065 & $<\mathbf{0 . 0 0 0 1}$ \\
Among years & 3 & 0.0016 & 0.07 & SC 0.0007 & 0.2230 \\
Within samples & 1202 & 2.2909 & 99.28 & ST 0.0072 & $<\mathbf{0 . 0 0 0 1}$ \\
Total & 1207 & 2.3075 & & & \\
\hline
\end{tabular}

apparent between the Casco Bay and Cape Cod juveniles $\left(F_{\mathrm{ST}}=0.0043\right)$. When visualized in a PCA with the data from the adult spawning complexes, the pooled Massachusetts Bay October cod samples clustered within the northern spring complex, and the juveniles from Massachusetts Bay spring, northeastern Cape Cod and Casco Bay clustered within the southern complex (Fig. 6).

Mixture analysis was used to assign proportions of the juvenile samples to the 2 spawning complexes. Assignments to specific spawning aggregations within the complexes were not attempted due to the low levels of differentiation among some of the aggregations within a complex (Table 5). The Georges Bank spawning population was not used in the mixture analysis because it was only weakly differentiated from the Gulf of Maine populations and, given the anticyclonic circulation (Lough et al. 2006), was unlikely to be the source population for young-of-the-year juvenile cod on nursery grounds in the Gulf of Maine.

Before mixture analysis, a 'leave-one-out' crossvalidation test and a $100 \%$ fishery simulation test were conducted to assess the power of the genetic data for assignment of juvenile proportions to the spawning complexes (Table 9). The percent scores from the cross-validation test ranged from 75.3 to $83.9 \%$ for the southern complex and 54.1 to $63.1 \%$ for the northern spring complex. The $100 \%$ fishery simulation consisted of simulating a mixture sample composed entirely of one population and then assigning those individuals back to the same population. The percentage of correct scores in this simulation was greater than in the validation test and ranged from 82.6 to $95.4 \%$ in the southern complex and from 76.2 to $86.0 \%$ in the northern spring complex.

Approximately $98 \%$ of the pooled Massachusetts Bay fall juvenile cod collection was assigned to the northern spring complex through mixture analysis (Fig. 7). The majority ( 85\%) of the juveniles from the Massachusetts Bay spring collection were assigned to the southern complex. Similarly, the majority $(\sim 79 \%)$ of the Cape Cod juveniles were assigned to the southern complex. Mixture analysis of the Casco Bay immature collection was more equivocal, with approximately 63 and $37 \%$ assignment to the southern and northern spring complexes, respectively. The confidence intervals for these assignments, however, overlapped extensively and

Table 8. Gadus morhua. Population differentiation of juvenile Atlantic cod. Allelic differentiation p-values are shown above the diagonal break; pairwise population $F_{\mathrm{ST}}$ values with p-values in parentheses are shown below the diagonal. Abbreviated sample names are defined in Table 1. Bold text indicates significance following standard Bonferroni correction $(\mathrm{p} \leq 0.005)$. Significance at 0.05 and 0.01 levels are indicated by $^{*}$ and ${ }^{* *}$, respectively

\begin{tabular}{|lccccc|}
\hline & CBSJ & MBWJ1 & MBWJ2 & MBSJ & CCWJ \\
\hline CBSJ & & $0.0073^{* *}$ & $<\mathbf{0 . 0 0 0 1}$ & 0.2795 & $\mathbf{0 . 0 0 3 2}$ \\
& & & & & \\
MBWJ1 & 0.0058 & & 0.0859 & $0.0135^{*}$ & $\mathbf{0 . 0 0 1 5}$ \\
& $(0.0100)^{*}$ & & & & \\
MBWJ2 & $\mathbf{0 . 0 1 2 4}$ & 0.0043 & & $<\mathbf{0 . 0 0 0 1}$ & $<\mathbf{0 . 0 0 0 1}$ \\
& $(\mathbf{0 . 0 0 5 0 )}$ & $(0.1200)$ & & & 0.6810 \\
MBSJ & 0.0000 & 0.0099 & $\mathbf{0 . 0 1 8 4}$ & & \\
& $(0.5500)$ & $(0.0800)$ & $\mathbf{( 0 . 0 0 5 0 )}$ & & \\
CCWJ & 0.0043 & $\mathbf{0 . 0 0 7 0}$ & $\mathbf{0 . 0 1 4 0}$ & -0.0011 & \\
& $(0.0200)^{*}$ & $\mathbf{( 0 . 0 0 5 0 )}$ & $\mathbf{( 0 . 0 0 5 0 )}$ & $(0.7300)$ & \\
\hline
\end{tabular}




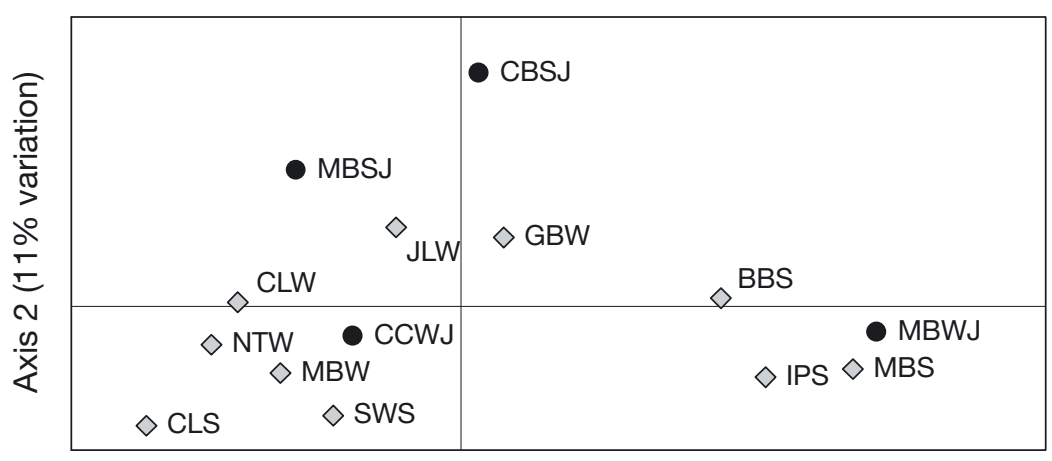

Axis 1 (68\% variation)

Fig. 6. Gadus morhua. Principal component analysis of pairwise population $F_{\mathrm{ST}}$ values for $(\diamond)$ spawning and $(\bullet)$ juvenile Atlantic cod samples. Abbreviated sample names are defined in Table 1. Percent values refer to the percentage of variation explained by each axis

Table 9. Gadus morhua. Test of the accuracy of genetic stock identification using a leave-one-out cross-validation test and a $100 \%$ fishery simulation test in Oncor. Percent correct values refer to the percentage of individuals correctly assigned to each of the 2 reporting groups, northern spring complex (NSC) and southern complex (SC). The Georges Bank population was not included in this analysis (see 'Results'). SD values and 95\% CI refer to the $100 \%$ simulation. Abbreviated sample names are defined in Table 1

\begin{tabular}{|lccrrr|}
\hline Population & $\begin{array}{c}\text { Assigned } \\
\text { reporting } \\
\text { group }\end{array}$ & $\begin{array}{c}\text { Percent correct } \\
\text { Leave-one- } \\
\text { out test }\end{array}$ & $\begin{array}{c}100 \% \\
\text { simulation }\end{array}$ & & SD \\
\hline BBS & NSC & 54.1 & 76.8 & 9.89 & $56.09,94.46$ \\
IPS & NSC & 55.9 & 76.2 & 10.01 & $55.11,94.50$ \\
MBS & NSC & 63.1 & 86.0 & 8.17 & $68.19,99.76$ \\
JLW & SC & 75.3 & 82.6 & 9.77 & $61.49,99.88$ \\
MBW & SC & 77.3 & 90.0 & 7.63 & $72.53,100.00$ \\
SWS & SC & 77.7 & 85.4 & 9.23 & $65.00,99.99$ \\
NTW & SC & 80.8 & 91.6 & 7.10 & $75.45,100.00$ \\
CLW & SC & 83.9 & 93.8 & 5.70 & $80.36,100.00$ \\
CLS & SC & 82.7 & 95.4 & 5.20 & $82.37,100.00$ \\
\hline
\end{tabular}

suggested that the Casco Bay fish were of heterogeneous origin. Notably, the Casco Bay fish were of an older and more mobile life stage and, therefore, were not probably sampled from a juvenile nursery, as were the young-of-the-year collections.

\section{DISCUSSION}

\section{Spawning stock structure}

In this study, we found evidence for fine-scale genetic differentiation among spatially and seasonally divergent spawning populations of Atlantic cod in US waters. This differentiation was stable over a $5 \mathrm{yr}$ period. Documentation of temporal stability of the genetic structure of fish populations is critical for identifying meaningful population units for management
(Waples 1998, Waples et al. 2008, ICES 2009).

We showed that the majority of the genetic variation among Atlantic cod spawning populations in US waters can be partitioned into 3 major complexes: (1) a northern spring coastal complex, which spawns in coastal Gulf of Maine waters from Massachusetts Bay to Bigelow Bight in the spring; (2) a southern complex, which spawns within the inshore Gulf of Maine in the winter and at different offshore locations and seasons within the GOM and south of Cape Cod; and (3) a population on the northeast peak of Georges Bank, which spawns in the late winter and is differentiated from the populations south of Cape Cod and the inshore GOM, but similar to the offshore GOM. Finer scale population structuring also occurs within the complexes, including weak differentiation between cod populations in the offshore GOM and southern New England waters (south of Cape Cod), as well as differentiation between populations south of Cape Cod (e.g. Cox Ledge and Nantucket Shoals).

One of our most significant findings is that of genetic differentiation among seasonally separated spawning groups of cod that overlap spatially in the GOM. In earlier work (Wirgin et al. 2007), we found a genetically divergent spring spawning population in Ipswich Bay. Herein we determined that this genetically distinct group of cod occurs in inshore GOM waters from Massachusetts Bay north to at least Bigelow Bight, and this population structure is stable over a $5 \mathrm{yr}$ period. This northern spring complex (NSC) appears to have fidelity to the coastal GOM region during the spring and early summer months. During the winter months, a genetically distinct group of cod, the southern complex (SC), spawns in the same geographic locations (Massachusetts and Ipswich bays). The populations that spawn in the inshore GOM in the winter are genetically similar to spring and winter spawning populations on Stellwagen Bank, Jeffreys Ledge and the southern New England waters of Cox Ledge and Nantucket Shoals. This indicates greater potential gene flow among populations in the $\mathrm{SC}$, which may be a consequence of early life stage dispersal patterns or adult migrations.

The weak but statistically significant differentiation observed in this study (overall $F_{\mathrm{ST}}=0.0044$ and $F_{\mathrm{ST}}=$ 


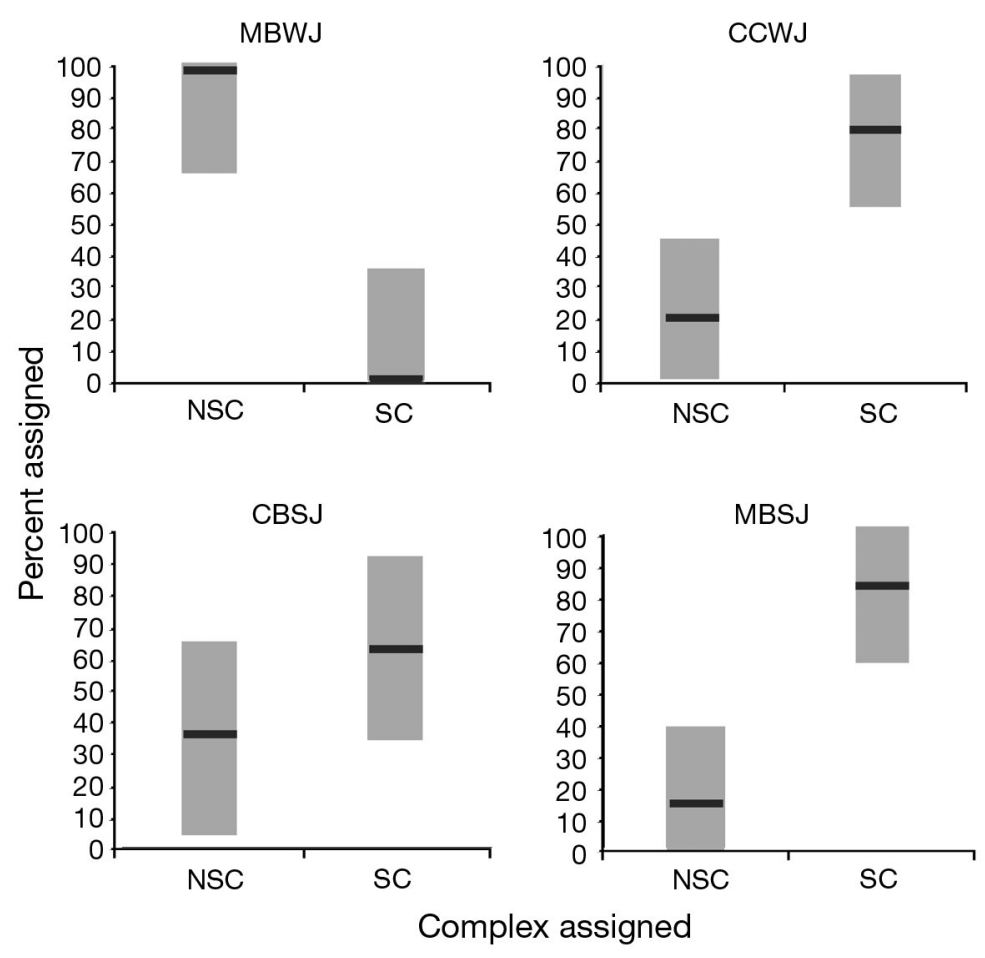

Fig. 7. Gadus morhua. Percentage (black bars) and 95\% confidence intervals (gray rectangles) of juvenile samples assigned by mixture analysis to reporting groups of northern spring complex (NSC) and southern complex

(SC). Abbreviated sample names are defined in Table 1

0.0085 between the 2 most divergent spawning complexes) is consistent with findings from other studies of Atlantic cod populations over similar geographic scales, although direct comparisons between studies are confounded by the use of different markers. Beacham et al. (2002) employed many of the same markers as we did in this study, including Gmo132 and PanI, and found an average $F_{\text {ST }}$ of 0.008 among populations in Newfoundland and Labrador, Canada. Studies employing the PanI locus in northeastern Atlantic and Icelandic waters, however, found much greater differentiation than we found herein (e.g. Skarstein et al. 2007, Pampoulie et al. 2008a,b). In the present study, we also found differences among discrete populations within a spawning complex $\left(F_{\mathrm{ST}}=0.0039\right.$ to 0.0061 ) that were consistent with fine-scale differences documented among nearby fjords (separated by 60 to $300 \mathrm{~km})$ in Norway $\left(F_{\mathrm{ST}}=0.0013\right.$ to 0.0054 , PanI not used, Knutsen et al. 2003) and among cod in Icelandic waters $\left(F_{\mathrm{ST}}=0.0030\right.$, excluding PanI, Pampoulie et al. 2006). Weak genetic differentiation may be a result of the recent origin of cod populations (Pampoulie et al. 2008a). Yet, even very small $F_{\mathrm{ST}}$ values among marine fish populations can coincide with migration rates that are sufficiently low to suggest demographic independence (Waples et al. 2008).

\section{Mechanisms of population structuring}

Processes that contribute to gene flow and thereby influence the structure of marine fish populations operate across the entire life cycle; they include adult migratory behaviors, site fidelity, dispersion of early life stages and settlement on juvenile nursery grounds (Metcalfe 2006). The genetic population structure we observed in the present study is consistent with recent findings about adult movements and early life history ecology of Atlantic cod in the GOM.

Using conventional tagging and acoustic tracking studies, Howell et al. (2008) documented the presence of 2 distinct groups of cod spawning in Ipswich Bay during the spring and winter. The spring spawning fish (NSC of our study) do not appear to undertake extensive migrations, but have limited movements along the GOM coast, exhibit spawning site fidelity and have been characterized as 'sedentary residents' (after Robichaud \& Rose 2004, Howell et al. 2008, Tallack 2009). Cod comprising the $\mathrm{SC}$ appear to display more extensive adult movements than do those of the NSC. Cod from Cape Cod and the Great South Channel migrate both into the GOM and south towards the Nantucket Shoals and beyond (Tallack 2009). Cod from the southern GOM region may also use the Great South Channel as a migration corridor to the Nantucket Shoals (Gröger et al. 2007). The genetic similarity of the resting cod aggregations from New Jersey to the SC suggest that there may be demographic connections that extend as far south as the New York Bight. The tagging data also show limited migration between Georges Bank and southern New England waters (Tallack 2009), which is consistent with the genetic data and indicates a role for the Great South Channel in separating Georges Bank cod from these other populations (Lage et al. 2004, Wirgin et al. 2007).

Temporal differences in spawning time combined with differences in migratory behavior may serve to separate populations from the NSC and SC demographically despite some spatial overlap in their geographic locations at certain times of the year. Similarly, in the northeastern Atlantic Ocean, 2 genetically distinct groups of Atlantic cod, the northeastern Arctic cod and the northern coastal cod, differ in migratory behavior with the latter being characterized as a more sedentary inshore population (Westgaard \& Fevolden 2007). These findings are consistent with an expanding body of research that recognizes biocomplexity and 
life-cycle diversity in fish (e.g. Ruzzante et al. 2006, Kerr et al. 2009b).

Gene flow is not only a function of adult behaviors, but also of egg and larval dispersal. The classical view holds that demographic connections are maintained across wide geographic locations for marine organisms with pelagic eggs and larvae, which may disperse widely with ocean currents. Yet, recent research shows that larval recruitment for some marine organisms, including cod, may occur on a local scale. In Atlantic cod, local recruitment has been linked to fine-scale habitat associations (Bradbury et al. 2008) and egg and larval retention has been hypothesized as a mechanism promoting fine-scale genetic structure (Knutsen et al. 2003, 2007, Jorde et al. 2007). Norwegian cod may select spawning sites within sheltered fjords to minimize advection of pelagic larvae (Knutsen et al. 2007). In the GOM, acoustic tracking of spring-spawning cod in Ipswich Bay revealed that spawning activity is focused at vertically elevated bathymetric features where adults aggregate during the spawning period (Siceloff 2009). Spawning in proximity to these features may promote local retention of larvae within the bay.

The outcome of egg and larval transport (dispersal) is a function of spawning location in relation to the coastal currents in the western GOM (Huret et al. 2007). The general cyclonic circulation of the Gulf of Maine Coastal Current does not favor local retention, but rather a southwestward flow to downstream or offshore from juvenile nursery sites. This circulation pattern supports connectivity among spawning grounds within the GOM and downstream nurseries within Massachusetts and Cape Cod bays and the Nantucket Shoals (Huret et al. 2007). For offshore spawning sites, advection of larvae is likely to occur to sites farther offshore (Huret et al. 2007). Larval transport varies both annually and seasonally, however. In May and June, winds favorable for downwelling may cause the coastal currents to bypass spawning grounds within Ipswich and Massachusetts bays, thereby promoting larval retention within these bays, while upwelling winds in January and February sweep larvae offshore (Churchill 2009). These seasonal differences in advection and retention are another possible mechanistic explanation for the genetic patterns we observed. Larval retention of NSC cod promotes the genetic distinctiveness of these populations via self-recruitment, while greater connectivity within the SC is facilitated by advection of eggs and larvae. These differential larval transport patterns are supported by the results of our juvenile mixture analysis. Juvenile cod, collected in Massachusetts Bay in the fall and spring, originated from spawning in the preceding season within the inshore GOM of the NSC or SC, respectively, and were retained within the bay. Juveniles collected in the fall from Cape Cod Bay, however, originated from the SC; they were probably spawned on Stellwagen Bank during the previous spring and drifted into Cape Cod Bay via the western GOM coastal current.

Larval recruitment in relation to ocean currents on Georges Bank supports the genetic distinctiveness of these fish from the populations south of Cape Cod, but not from the GOM. The anticyclonic, clockwise gyre on Georges Bank (Lough et al. 2006) may serve to retain larvae locally and limit their dispersal to either the inshore GOM or southern New England waters. Larvae spawned within the GOM, however, especially on offshore or nearshore sites, may drift with the coastal currents toward Georges Bank (Huret et al. 2007), resulting in some weak connectivity among these spawning populations despite limited adult movements. Consistent with this explanation, the spawning aggregations on Stellwagen Bank and Jeffrey's Ledge were the most genetically similar of all stocks to the Georges Bank cod.

\section{Natural selection and local adaptation}

The genetic differences in this study were due primarily to 2 potentially non-neutral loci (Gmo132 and PanI). Gmo132 is assumed to be under hitch-hiking selection with a gene of unknown function (Nielsen et al. 2006). The PanI locus codes for an integral membrane-trafficking protein (pantophysin) expressed in cytoplasmic microvesicles (Haass et al. 1996); however, its exact function and the basis for selection at this locus are unknown (Jónsdóttir et al. 2008). The population structure we detected with these 2 selected loci could not be detected with the neutral loci alone, although the BARRIER analysis showed that the major genetic discontinuities driven by Gmo132 and PanI were also supported by a subset of the neutral loci. Similarly, selected loci, including PanI, Gmo132, and other non-neutral microsatellites, have been found to drive the genetic differences found among other cod populations (e.g. Beacham et al. 2002, Pampoulie et al. 2006, Westgaard \& Fevolden 2007; but see Pampoulie et al. 2008a,b for differentiation detected with neutral markers alone).

Population differentiation at selected loci is interpreted differently than at neutral loci (Nielsen et al. 2006), as it is indicative of local ecological adaption to environmental selection pressures. Adaptive divergence can occur over much shorter time scales than can neutral genetic differentiation (Endler 1986, Cano et al. 2008), resulting in genetic differentiation of a greater magnitude for selected versus neutral loci (Beaumont \& Balding 2004). Although selected loci are 
therefore inappropriate for making inferences about population processes, such as migration rates and effective population size, they can serve an important function in genetic stock identification (Nielsen et al. 2006, Westgaard \& Fevolden 2007, ICES 2009). The adaptive differences underlying variation at selected loci may have important management implications (Crandall et al. 2000, Conover et al. 2006, Hauser \& Carvalho 2008, ICES 2009).

Variation in PanI has been correlated with environmental factors, including water temperature, salinity, depth, latitudinal gradients and inshore/offshore migrations (Beacham et al. 2002, Case et al. 2005, Sarvas \& Fevolden 2005, Pampoulie et al. 2006, Westgaard \& Fevolden 2007), with potential fitness effects reported (Otterlei et al. 1999, Case et al. 2006, Jónsdóttir et al. 2008). The patterns are not consistent across studies and geographic regions, however, indicating that the selective pressures may be complex (Jónsdóttir et al. 2008).

On a macrogeographic scale, Pampoulie et al. (2008a) found that PanIBB genotypes occur only in the northwestern Atlantic Ocean (Iceland and Canada), while the northeastern Atlantic is dominated by AA and $\mathrm{AB}$ genotypes. In Canadian waters all 3 genotypes are present, with a trend for higher frequencies of the $\mathrm{B}$ allele in offshore and southern populations, while A is more prevalent in northern and inshore populations (Beacham et al. 2002). Our results show an extension of the latitudinal and inshore/offshore gradient found in Canadian waters. Genotype AA is extremely rare in the populations in the present study (occurs in 3 of 1581 adults, all in the NSC), and a higher frequency of the A allele occurs in the NSC, which is thought to be a resident coastal population, than in the $\mathrm{SC}$ and Georges Bank, which consist predominantly of BB genotypes and include offshore and presumably more migratory populations. Our findings are consistent with studies hypothesizing a selective advantage of the $\mathrm{B}$ allele in Atlantic cod with offshore migrations into deeper and higher salinity waters (Pampoulie et al. 2006, 2008c, Westgaard \& Fevolden 2007, Jónsdóttir et al. 2008, Árnason et al. 2009). It is important to note, however, that the differences in PanI allele frequencies in this study were small relative to the differences found in other studies, which might be at least in part a function of the small spatial scale.

Notably, the differences in PanI allele frequencies in this study were greater in the juveniles than the adults (PanI $F_{\mathrm{ST}}$ value for the juvenile samples was nearly double that of the adults, Table 2). This result may be suggestive of post-settlement selection on the early life stages, which occurs in the face of ongoing gene flow. Further research into the environmental correlates and selective forces acting upon PanI is warranted.

\section{Conclusion and management implications}

The definition of stocks as demographically independent units is at the core of marine conservation and management (Waples et al. 2008). By this definition, our results do not support the current stock delineations for Atlantic cod in US waters. Consistent with previous studies (Lage et al. 2004, Wirgin et al. 2007), we found strong evidence for a fine-scale spatial and seasonal population genetic structure that contradicts the 2-stock management model. The Gulf of Maine stock consists of 2 seasonally divergent spawning groups, while the Georges Bank population is divergent from the southern New England and perhaps New York Bight populations, with which it is currently grouped for management purposes. The southern New England populations maintain connectivity with the winter-spawning inshore GOM population and both spring- and winter-spawning offshore populations of the GOM. Our results suggest, therefore, that Atlantic cod are broadly structured into 3 complexes: (1) a northern spring-spawning coastal complex in the GOM, (2) a southern complex consisting of winterspawning inshore GOM, offshore GOM and sites south of Cape Cod, and (3) a Georges Bank complex. This population structure is temporally stable and the magnitude of genetic differentiation, while not large, is sufficient to assign juveniles to their complex of origin via mixture modeling.

Our findings are in accordance with a recent awareness of a mismatch between biological and management units for a number of commercially important marine fishes (Reiss et al. 2009). Our results also add to the growing body of knowledge that marine fish populations do not conform to the classical panmictic population view, but rather are characterized by population structure on a much finer scale than expected from their dispersal and migratory abilities (Hauser \& Carvalho 2008). It may be warranted to re-evaluate current management units and tailor management plans toward this finer scale in light of the importance of managing for biologically meaningful units, based on concepts of ecological exchangeability and maintaining biodiversity and biocomplexity (Crandall et al. 2000, Ruzzante et al. 2006, Bradbury et al. 2008, Cadrin \& Secor 2009, ICES 2009, Reiss et al. 2009).

Future studies should focus on determining the selective forces shaping the adaptive population divergence and identifying additional informative markers to enhance our ability for differentiating among subpopulations within the US stock complexes of Atlantic cod. To this end, some of the recently identified geneassociated loci (e.g. Stenvik et al. 2006b, Wesmajervi et al. 2007, Delghandi et al. 2008, Moen et al. 2008) may prove useful. 
Acknowledgements. Funding for this research was provided by the Northeast Consortium and the New Hampshire Agricultural Experiment Station. Support of the facilities core of the New York University NIEHS Center Grant ES00260 also is acknowledged. We thank the following commercial fishers for their help in sample collection: C. Bouchard, J. Carver, D. Goethal, F. Mirarchi, C. Odlin and P. Wells. L. Van Eeckhaute from the Canada Department of Fisheries and Oceans provided fin clip samples from Georges Bank cod. J. King, D. Salerno and M. Szymanski from the Massachusetts Division of Marine Fisheries and S. Cadrin, J. Loehrke and D. Martins from the University of Massachusetts Dartmouth also provided samples. We thank Captains B. Bogan and H. Bogan for fin clip samples from cod from the New York Bight. We owe special thanks to J. Anderson from the University of New Hampshire Hubbard Center for Genome Studies for his dedicated expertise in running the automated sequencer. C. Brauer, J. Deming, M. Lubicky, S. Petren and C. Van Thof helped with DNA extractions. L. Fenderson helped construct Figs. $1 \& 4$. Many of the ideas presented in this paper benefitted from fruitful discussions with J. Runge, S. Cadrin, J. Churchill, J. Gabrowski, H. Howell, G. Sherwood and S. Tallack. We are grateful to S. Cadrin and 3 anonymous reviewers for valuable comments on the manuscript. This is scientific contribution no. 2428 from the New Hampshire Agricultural Experiment Station.

\section{LITERATURE CITED}

Anderson EC, Waples RS, Kalinowski ST (2008) An improved method for predicting the accuracy of genetic stock identification. Can J Fish Aquat Sci 65:1475-1486

Antao T, Lopes A, Lopes RJ, Beja-Pereira A, Luikart G (2008) LOSITAN: a workbench to detect molecular adaptation based on an $F_{s t}$-outlier method. BMC Bioinformatics 9: 323-327

Árnason E, Hernandez UB, Kristinsson K (2009) Intense habitat-specific fisheries-induced selection at the molecular PanI locus predicts imminent collapse of a major cod fishery. PLoS ONE 45(5):e5529

> Beacham TD, Brattey J, Millar KM, Withler RE (2002) Multiple stock structure of Atlantic cod (Gadus morhua) off Newfoundland and Labrador determined from genetic variation. ICES J Mar Sci 59:650-655

Beaumont MA, Balding DJ (2004) Identifying adaptive genetic divergence among populations from genome scans. Mol Ecol 13:969-980

Beaumont MA, Nichols RA (1996) Evaluating loci for use in the genetic analysis of population structure. Proc Biol Sci 263:1619-1626

Bradbury IR, Laurel BJ, Robichaud D, Rose GA and others (2008) Discrete spatial dynamics in a marine broadcast spawner: re-evaluating scales of connectivity and habitat associations in Atlantic cod (Gadus morhua L.) in coastal Newfoundland. Fish Res 91:299-309

Brooker AL, Cook D, Bentzen P, Wright JM, Doyle RW (1994) Organization of microsatellites differs between mammals and cold-water teleost fishes. Can J Fish Aquat Sci 51: 1959-1966

Cadrin SX, Secor DH (2009) Accounting for spatial population structure in stock assessment: past, present and future. In: Beamish RJ, Rothschild BJ (eds) The future of fisheries science in North America. Fish and Fisheries Series, Vol 31. Springer, Heidelberg, p 405-426

Cano JM, Mäkinen HS, Leinonen T, Freyhof J, Merilä J (2008) Extreme neutral genetic and morphological divergence supports classification of Adriatic three-spined stickleback
(Gasterosteus aculeatus) populations as distinct conservation units. Biol Conserv 141:1055-1066

Case RA, Hutchinson WF, Hauser L, van Oosterhout C, Carvalho GR (2005) Macro- and micro-geographic variation in pantophysin (PanI) allele frequencies in NE Atlantic cod Gadus morhua. Mar Ecol Prog Ser 301:267-278

> Case RA, Hutchinson WF, Hauser L, Buehler V and others (2006) Association between growth and Pan I* genotype within Atlantic cod full-sibling families. Trans Am Fish Soc 135:241-250

Churchill J (2009) What maintains the western Gulf of Maine stock? In: Proceedings of exploring fine-scale ecology for groundfish in the Gulf of Maine and Georges Bank. Gulf of Maine Research Institute, Portland, ME. www.gmri.org/ community (accessed 24 July 2009)

Collette BB, Klein-MacPhee G (2002) Bigelow and Schroeder's fishes of the Gulf of Maine. Smithsonian Institute Press, Washington, DC

Conover DO, Clarke LM, Munch SB, Wagner GN (2006) Spatial and temporal scales of adaptive divergence in marine fishes and the implications for conservation. J Fish Biol 69:21-47

> Crandall KA, Bininda-Emonds ORP, Mace GM, Wayne RK (2000) Considering evolutionary processes in conservation biology. Trends Ecol Evol 15:290-295

Delghandi M, Stenvik J, Nilsen F, Wesmajervi MS, Fjalestad KT, Damsgård B (2008) Identification and characterisation of nine new gene-associated microsatellite markers for Atlantic cod (Gadus morhua L.). Conserv Genet 9:747-749

> Dieringer D, Schlötterer C (2003) Micrsoatellite analyser (MSA): a platform independent analysis tool for large microsatellite data sets. Mol Ecol Notes 3:167-169

Endler JA (1986) Natural selection in the wild. Princeton University Press, Princeton, NJ

Goudet J (1995) FSTAT (version 1.2): a computer program to calculate F-statistics. J Hered 86:485-486

Gröger JP, Rountree RA, Thygesen UH, Jones D, Martins D, $\mathrm{Xu}$ Q, Rothchild BJ (2007) Geolocation of Atlantic cod (Gadus morhua) movements in the Gulf of Maine using tidal information. Fish Oceanogr 16:317-335

> Haass NK, Kartenbeck J, Leube RE (1996) Pantophysin is a ubiquitously expressed synaptophysin homologue and defines constitutive transport vesicles. J Cell Biol 134: $731-746$

Hauser L, Carvalho GR (2008) Paradigm shifts in marine fisheries genetics: ugly hypotheses slain by beautiful facts. Fish Fish 9:333-362

> Hedrick PW (2005) A standardized genetic differentiation measure. Evolution 59:1633-1638

> Howell WH, Morin M, Rennels N, Goethal D (2008) Residency of adult Atlantic cod (Gadus morhua) in the western Gulf of Maine. Fish Res 91:123-132

> Huret M, Runge JA, Chen C, Cowles G, Xu Q, Pringle JM (2007) Dispersal modeling of fish early life stages: sensitivity with application to Atlantic cod in the western Gulf of Maine. Mar Ecol Prog Ser 347:261-274

> Hutchings JA, Swain DP, Rowe S, Eddington JD, Velmurugu P, Brown JA (2007) Genetic variation in life-history reaction norms in a marine fish. Proc Biol Sci 274:1693-1699

Hutchinson WF, Carvalho GR, Rogers SI (2001) Marked genetic structuring in localised spawning populations of cod Gadus morhua in the North Sea and adjoining waters, as revealed by microsatellites. Mar Ecol Prog Ser 223: 251-260

ICES (2009) Report of the working group on the application of genetics in fisheries and mariculture (WGAGFM). ICES CM 2009/MCC:03, Copenhagen 
Iles TD, Sinclair M (1982) Atlantic herring: stock discreteness and abundance. Science 215:627-633

Jakobsdóttir KB, Jörundsdóttir PD, Skínidóttir S, Hjörleifsdóttir S, Hreggvidsson GO, Daníelsdóttir AK, Pampoulie C (2006) Nine new polymorphic microsatellite loci for the amplification of archived otolith DNA of Atlantic cod, Gadus morhua L. Mol Ecol Notes 6:337-339

> Jones GP, Milicich MJ, Emslie MJ, Lunow C (1999) Selfrecruitment in a coral reef fish population. Nature 402: 802-804

Jones GP, Planes S, Thorrold SR (2005) Coral reef fish larvae settle close to home. Curr Biol 15:1314-1318

> Jónsdóttir IG, Marteinsdóttir G, Pampoulie C (2008) Relation of growth and condition with the Pan I locus in Atlantic cod (Gadus morhua L.) around Iceland. Mar Biol 154: 867-874

Jorde PE, Knutsen H, Espeland SH, Stenseth NC (2007) Spatial scale of genetic structuring in coastal cod Gadus morhua and geographic extent of local populations. Mar Ecol Prog Ser 343:229-237

Kerr LA, Cadrin SX, Secor DH (2009a) Consequences of spatial structure and connectivity to productivity and persistence of local and regional populations. ICES CM 2009/ $\mathrm{H}: 02$, Copenhagen

Kerr LA, Secor DH, Piccoli PM (2009b) Partial migration of fishes as exemplified by the estuarine-dependent white perch. Fisheries 34:114-123

Knutsen H, Jorde PE, Andre C, Stenseth NC (2003) Finescaled geographic population structuring in a highly mobile marine species: the Atlantic cod. Mol Ecol 12: 385-394

Knutsen H, Olsen EM, Ciannelli L, Espeland SH and others (2007) Egg distribution, bottom topography and smallscale cod population structure in a coastal marine system. Mar Ecol Prog Ser 333:249-255

Lage C, Kuhn K, Kornfield I (2004) Genetic differentiation among Atlantic cod (Gadus morhua) from Browns Bank, Georges Bank, and Nantucket Shoals. Fish Bull 102: 289-297

Larkin PA (1977) An epitaph for the concept of maximum sustained yield. Trans Am Fish Soc 106:1-11

Lewis PO, Zaykin D (2001) Genetic data analysis: computer program for the analysis of allelic data. Version 1.0 (dl6c). lewis.eeb.uconn.edu/lewishome/software.html

Lough RG, Hanna CG, Berrien P, Brickman D, Loder JW, Quinlan JA (2006) Spawning pattern variability and its effect on retention, larval growth and recruitment in Georges Bank cod and haddock. Mar Ecol Prog Ser 310: 193-212

Manni F, Guérard E, Heyer E (2004) Geographic patterns of (genetic, morphologic, linguistic) variation: how barriers can be detected by using Monmonier's algorithm. Hum Biol 76:173-190

Mayo RK, Col LA (2006) The 2005 assessment of the Gulf of Maine Atlantic cod stock. US Department of Commerce, Northeast Fisheries Science Center Reference Document 02-6, Woods Hole, MA

McIntyre TM, Hutchings JA (2003) Small-scale temporal and spatial variation in Atlantic cod (Gadus morhua) life history. Can J Fish Aquat Sci 60:1111-1121

Meirmans PG (2006) Using the AMOVA framework to estimate a standardised genetic differentiation measure. Evolution 60:2399-2402

> Metcalfe JD (2006) Fish population structuring in the North Sea: understanding processes and mechanisms from studies of the movements of adults. J Fish Biol 69(Suppl C):48-65
Miller KM, Le KD, Beacham TD (2000) Development of triand tetranucleotide repeat microsatellite loci in Atlantic cod (Gadus morhua). Mol Ecol 9:238-239

> Moen T, Hayes B, Nilsen F, Delghandi M and others (2008) Identification and characterisation of novel SNP markers in Atlantic cod: evidence for directional selection. BMC Genetics 9:18

Nei M (1987) Molecular evolutionary genetics. Columbia University Press, New York

Nielsen EE, Hansen MM, Ruzzante DE, Meldrup D, Grønkjær P (2003) Evidence of a hybrid zone in Atlantic cod (Gadus morhua) in the Baltic and the Danish Belt Sea revealed by individual admixture analysis. Mol Ecol 12:1497-1508

> Nielsen EE, Hansen MM, Meldrup D (2006) Evidence of microsatellite hitch-hiking selection in Atlantic cod (Gadus morhua L.): implications for inferring population structure in nonmodel organisms. Mol Ecol 15:3219-3229

O'Brien L, Burnett J, Mayo RK (1993) Maturation of nineteen species of finfish off the northeast coast of the United States, 1985-1990. NOAA Tech Rep NIMFS 113

Otterlei E, Nyhammer G, Folkvord A, Steffansson SO (1999) Temperature- and size-dependent growth of larval and early juvenile Atlantic cod (Gadus morhua): a comparative study of Norwegian coastal cod and northeast Arctic cod. Can J Fish Aquat Sci 56:2099-2111

Palumbi SR (2003) Population genetics, demographic connectivity, and the design of marine reserves. Ecol Appl 13(Suppl Mar Reserv):146-158

Pampoulie C, Ruzzante DE, Chosson V, Jörundsdóttir TD and others (2006) The genetic structure of Atlantic cod (Gadus morhua) around Iceland: insight from microsatellites, the Pan I locus, and tagging experiments. Can J Fish Aquat Sci 63:2660-2674

> Pampoulie C, Stefánsson MO, Jörundsdóttir TD, Danilowicz BS, Daníelsdóttir AK (2008a) Recolonization history and large-scale dispersal in the open sea: the case study of the North Atlantic cod, Gadus morhua L. Biol J Linn Soc 94: 315-329

> Pampoulie C, Steingrund P, Stefánsson MO, Daníelsdóttir AK (2008b) Genetic divergence among East Icelandic and Faroese populations of Atlantic cod provides evidence for historical imprints at neutral and non-neutral markers. ICES J Mar Sci 65:65-71

Pampoulie C, Jakobsdótttir K, Marteinsdóttir G, Thorsteinsson V (2008c) Are vertical behaviour patterns related to the Pantophysin locus in the Atlantic cod (Gadus morhua L.)? Behav Genet 38:76-81

> Peakall R, Smouse PE (2006) GENALEX 6: genetic analysis in Excel. Population genetic software for teaching and research. Mol Ecol Notes 6:288-295

Pogson GH (2001) Nucleotide polymorphism and natural selection at the Pantophysin I (Pan I) locus in Atlantic cod, Gadus morhua (L.). Genetics 157:317-330

Raymond M, Rousset F (1995) GENEPOP (version 1.2) population genetic software for exact tests and ecumenicism. J Hered 86:248-249

Reiss H, Haloarau G, Dickey-Collas M, Wolff WJ (2009) Genetic population structure of marine fish: mismatch between biological and fisheries management units. Fish Fish 10:361-395

> Rice WR (1989) Analyzing tables of statistical tests. Evolution 43:223-225

Robichaud D, Rose GA (2004) Migratory behaviour and range in Atlantic cod: inference from a century of tagging. Fish Fish 5:185-214

> Ruzzante DE, Taggart CT, Cook D (1996a) Spatial and temporal variation in the genetic composition of a larval cod 
(Gadus morhua) aggregation: cohort contribution and genetic stability. Can J Fish Aquat Sci 53:2695-2705

Ruzzante DE, Taggart CT, Cook D, Goddard S (1996b) Genetic differentiation between inshore and offshore Atlantic cod (Gadus morhua) off Newfoundland: microsatellite DNA variation and antifreeze level. Can J Fish Aquat Sci 53:634-645

Ruzzante DE, Taggart CT, Cook D (1998) A nuclear DNA basis for shelf- and bank-scale population structure in northwest Atlantic cod (Gadus morhua): Labrador to Georges Bank. Mol Ecol 7:1663-1680

Ruzzante DE, Taggart CT, Cook D (1999) A review of the evidence for genetic structure of cod (Gadus morhua) populations in the NW Atlantic and population affinities of larval cod off Newfoundland and the Gulf of St. Lawrence. Fish Res 43:79-97

Ruzzante DE, Wroblewski JS, Taggart CT, Smedbol RK, Cook D, Goddard SV (2000) Bay-scale population structure in coastal Atlantic cod in Labrador and Newfoundland. J Fish Biol 56:431-447

Ruzzante DE, Mariani S, Bekkevold D, André C and others (2006) Biocomplexity in a highly migratory pelagic marine fish, Atlantic herring. Proc R Soc B Biol Sci 273:1459-1464

Sarvas TH, Fevolden SE (2005) Pantophysin (Pan I) locus divergence between inshore $\mathrm{v}$. offshore and northern $\mathrm{v}$. southern populations of Atlantic cod in the north-east Atlantic. J Fish Biol 67:444-469

Schneider S, Roessli D, Excoffier L (2000) Arlequin ver. 2.000: A software for population genetics data analysis. Genetics and Biometry Laboratory, University of Geneva, Geneva

Siceloff L (2009) Fine-scale activity, distribution, and habitat utilization of Atlantic cod (Gadus morhua) on the Ipswich Bay spawning ground. MS thesis, University of New Hampshire, Durham, NH

Skarstein TH, Westgaard JI, Fevolden SE (2007) Comparing microsatellite variation in north-east Atlantic cod (Gadus morhua L.) to genetic structuring as revealed by the pantophysin (PanI) locus. J Fish Biol 70C:271-290

Smedbol RK, Stephenson R (2001) The importance of managing within-species diversity in cod and herring fisheries of the north-western Atlantic. J Fish Biol 59:109-128

Stenvik J, Wesmajervi MS, Damsgård B, Delghandi M (2006a) Genotyping of pantophysin I (PanI) of Atlantic cod (Gadus morhua L.) by allele-specific PCR. Mol Ecol Notes 6:272-275

Stenvik J, Wesmajervi MS, Fjalestad KT, Damsgård B, Delghandi M (2006b) Development of 25 gene-associated microsatellite markers of Atlantic cod (Gadus morhua L.). Mol Ecol Notes 6:1105-1107

Editorial responsibility: Philippe Borsa, Montpellier, France
Svedäng H, Righton D, Jonsson P (2007) Migratory behavior of Atlantic cod Gadus morhua: natal homing is the prime stock-separating mechanism. Mar Ecol Prog Ser 345: $1-12$

Taggart CT (1997) Bank-scale migration patterns in northern cod. N Atl Fish Org Sci Counc Stud 29:51-60

Tallack SML (ed) (2009) Proceedings from a workshop to identify future research priorities for cod tagging in the Gulf of Maine, 12 February 2009. Northeast Fisheries Science Center Reference Document 09-09, Woods Hole, MA

Templeman W (1974) Migrations and intermingling of Atlantic cod (Gadus morhua) stocks of the Newfoundland area. J Fish Res Board Can 31:1073-1092

Thorrold SR, Latkoczy C, Swart PK, Jones CM (2001) Natal homing in a marine fish metapopulation. Science 291: 297-299

van Oosterhout C, Hutchinson WF, Wills DPM, Shipley P (2004) MICRO-CHECKER: software for identifying and correcting genotyping errors in microsatellite data. Mol Ecol Notes 4:535-538

- Waples RS (1998) Separating the wheat from the chaff: patterns of genetic differentiation in high gene flow species. J Hered 89:438-450

Waples RS, Punt AE, Cope JM (2008) Integrating genetic data into management of marine resources: How can we do it better? Fish Fish 9:423-449

Ward RD, Woodwark M, Skibinski DOF (1994) A comparison of genetic diversity levels in marine, fresh-water, and anadromous fishes. J Fish Biol 44:213-232

Weir BS, Cockerham CC (1984) Estimating F-statistics for the analysis of population structure. Evolution 38:1358-1370

Wesmajervi MS, Tafese T, Stenvik J, Fjalestad KJ, Damsgård B, Delghandi M (2007) Eight new microsatellite markers in Atlantic cod (Gadus morhua L.) derived from an enriched genomic library. Mol Ecol Notes 7:138-140

- Westgaard JI, Fevolden SE (2007) Atlantic cod (Gadus morhua L.) in inner and outer coastal zones of northern Norway display divergent genetic signature at non-neutral loci. Fish Res 85:306-315

Wirgin I, Waldman JR (2005) Use of nuclear DNA in stock identification: single copy and repetitive sequence markers. In: Cadrin SX, Friedland KD, Waldman JR (eds) Stock identification methods: applications in fisheries science. Elsevier Academic Press, Burlington, MA, p 331-370

Wirgin I, Kovach A, Maceda L, Roy NK, Waldman J, Berlinsky D (2007) Stock identification of Atlantic cod in U.S. waters using microsatellite and single nucleotide polymorphism DNA analyses. Trans Am Fish Soc 136:375-391

Submitted: September 28, 2009; Accepted: April 8, 2010

Proofs received from author(s): June 25, 2010 